\title{
Observaciones sobre el procedimiento judicial ateniense a propósito de Lisias XXIII
}

\author{
Enrique García Domingo \\ enriquegdom@yahoo.es
}

Recibido: 27-05-2015

Aceptado: 02-12-2015

\section{RESUMEN}

Se considera que el discurso XXIII de Lisias Contra Pancleón, impugnando que fuera de Platea fue pronunciado en una paragraphé o 'proceso de excepción', llamado en una fase inicial antigraphé. Sin embargo, una revisión de tales conceptos y, en general, de algunos aspectos del procedimiento judicial ateniense nos ha permitido llegar a la conclusión de que el citado discurso fue dirigido por el demandante, cliente del logógrafo, contra su adversario en una 'acción por falsos testimonios', dikē pseudomartyriōn.

Palabras clave: Lisias, derecho, lexicografía, literatura.

\begin{abstract}
It is thought that Lysias' speech XXIII, Against Pancleon, was delivered in a paragraphe or 'counter-indictment process', called antigraphe in an initial phase. However a review of these concepts and, in general, of some aspects of Athenian judicial procedure has allowed us to conclude that the mentioned speech was made by the plaintiff, client of the logographer, against the defendant in a 'action for false testimony', dike pseudomartyrion.
\end{abstract}

Keywords: Lysias, law, lexicography, literature.

0. A partir de Wilamowitz ${ }^{1}$ se considera que el discurso XXIII de Lisias Contra

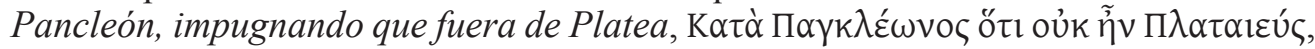
fue pronunciado en una $\pi \alpha \rho \alpha \gamma \rho \alpha \varphi \eta^{\prime}$, acción que en la fase inicial fue llamada, a tenor

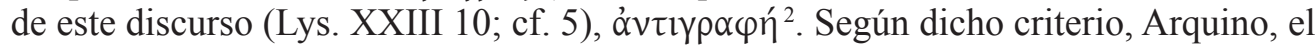
artífice de la paragraphé, no habría hecho más que perfeccionar un procedimiento que estaba ya anteriormente en ciernes ${ }^{3}$.

${ }^{1}$ Gernet - Bizos (1952 II: 95); Gil (1963: 251); Calvo Martínez (1995: 149).

${ }^{2}$ Para la introducción al discurso véase Gernet - Bizos (1955² II: 93-96); Gil (1963: 251-255); Todd (1993: 167-169; 2000: 245-247); Calvo Martínez (1995: 147-149).

${ }^{3}$ Por lo que nos refiere Isócrates en Excepción contra Calímaco (XVIII), escrito hacia el 400 a.C, se trata de un proceso novedoso, del que él por primera vez nos da noticia, lo cual, en principio, no es óbice para que tenga su punto de partida en otro anterior. El cliente de Isócrates, que interpone la excepción, se 
Al final de la guerra civil (403 a.C.), los ciudadanos atenienses consensuaron no emprender acciones legales, unos contra otros, por delitos cometidos durante la misma o bajo el régimen de los Treinta Tiranos. No mucho después de la citada fecha, en torno al 400 a.C., como refuerzo de esta medida, Arquino propuso la paragraphé o 'contra-acusación', mediante la cual el perseguido acusaba a su vez al perseguidor de infringir, en su acusación inicial, los acuerdos adoptados. Posteriormente, el procedimiento se amplió para alegar que una persecución era inadmisible por ser ilegal: cuando la tramitación del proceso era inadecuada, cuando el tipo de caso no estaba autorizado por la ley o la disputa había sido ya zanjada de otra manera. Por esos motivos la paragraphé o 'contra-acusación' se suele traducir por 'proceso de excepción'.

Los rasgos característicos de la paragraphé eran los siguientes: constituía una acción en sí misma que paralizaba y posponía la acción principal hasta que aquélla se hubiera celebrado. En ella los papeles estaban invertidos: el acusado en la acción original pasaba a ser el acusador, que hablaba primero y, al revés, el acusador, el acusado. Por medio de ella se decidía si la acción principal ( $\varepsilon u ̉ \theta v \delta ı$ kía) debía continuar o no, respectivamente, según ganara o perdiera este último. Quien perdía la paragraphé debía pagar la epobelía, un sexto del dinero o de la propiedad en litigio 4 .

Pues bien, expuesto esto, se han observado diferencias entre el proceso Contra Pancleón que ahora nos ocupa y la paragraphé, atribuidas al hecho de que ésta aparecía allí en un estadio preliminar: en primer lugar la excepción se designa con el nombre de antigraphé y no con el técnico de paragraphé, acuñado luego por Arquino. En segundo lugar, lo más importante, no constituye en el discurso de Lisias un proceso aparte, sino una fase previa de la acción principal, en la que el acusador sigue hablando el primero, en vez de ser una acción independiente en la que el acusado, asumiendo el papel de acusador, toma la iniciativa como sucede ya en la paragraphé propiamente dicha $^{5}$.

Teniendo en cuenta tales discrepancias, cabe preguntarse si el proceso Contra Pancleón es una paragraphé, llamada en un estadio incipiente antigraphé, o si se trata de algo distinto que no tiene nada que ver con aquélla y, en ese caso, ante qué tipo de acción nos encontramos. Resolver estas cuestiones constituye el objetivo final de esta investigación, asuntos que, sin embargo, no podremos abordar sin haber revisado antes algunos conceptos del procedimiento judicial ateniense. Tenemos un largo camino por delante hasta llegar a la meta.

1. Nuestra tarea consiste primeramente en tratar de determinar qué entendían los atenienses por antigraphé, para lo cual nos vamos a servir tanto de los testimonios de

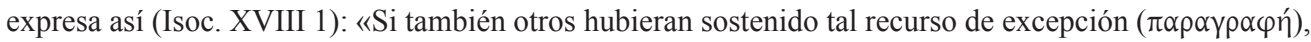
empezaría a hablar de la causa propiamente dicha; pero ahora es forzoso hacer primero una referencia a la ley por la que hemos comparecido, para que emitáis vuestro voto al conocer el motivo de nuestra disputa, y para que ninguno de vosotros se extrañe de que siendo yo el acusado hable antes que el acusador» (trad. de J. M. Guzmán Hermida).

${ }^{4}$ El estudio fundamental sobre la paragraphé es el libro de WolfF. Pueden leerse buenos resúmenes al respecto en Harrison (1971 II: 106-124); ISAGER AND HANSEN (1975: 123-131); MacDowell (1978: 214-219); TodD (1993: 135-9).

${ }^{5}$ GIL (1963: 252-253); Todd (1993: 108 n. 1). 
los lexicógrafos antiguos como de los autores griegos, sin descartar la información que nos proporcionan los estudios modernos al respecto.

1.1. Harpocración (s.v.), con el que aproximadamente coinciden los Lexica Se-

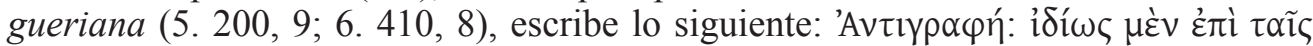

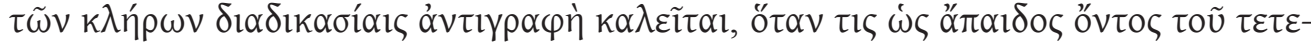

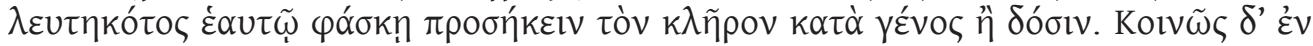

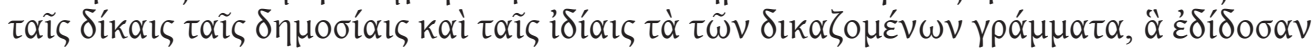

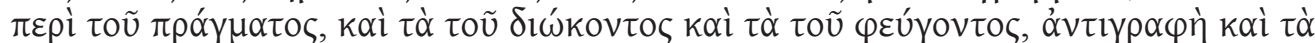

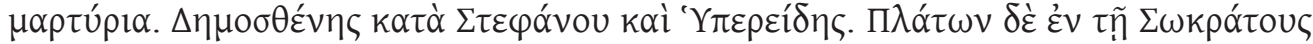

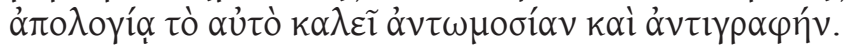

«Escrito de alegación o de réplica: particularmente, en los procesos de adjudicación judicial de herencias se llama escrito de réplica cuando uno, por suponer que el finado no tiene hijos, afirma que le corresponde a él mismo la herencia por parentesco o por legado. En general, en las acciones públicas y privadas los escritos que los litigantes entregaban sobre el caso, tanto los del acusador como los del acusado, se llamaban escrito de alegación, e igualmente sus testimonios. Demóstenes en Contra Estéfano e Hiperides. Platón en la Defensa de Sócrates llama lo mismo a la alegación jurada que al escrito de réplica».

1.1.1. Lo que nos refiere Harpocración en primer lugar está bien atestiguado en los textos literarios griegos y ha sido ya bien estudiado. Un hijo legítimo o nieto del

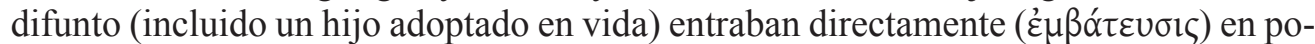
sesión de la herencia. Cualquiera otro que la reivindicara tenía que tener la aprobación del arconte epónimo. Si solo era uno el que la solicitaba y cumplía los requisitos, el arconte se la otorgaba. Tal procedimiento de reclamación y adjudicación se llamaba $\varepsilon ̇ \pi 1 \delta ı \kappa \alpha \sigma i ́ \alpha$. Pero si la herencia era disputada por otros contendientes, la controversia daba lugar a un proceso contencioso ante un tribunal presidido por el arconte, deno-

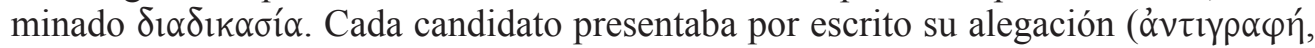

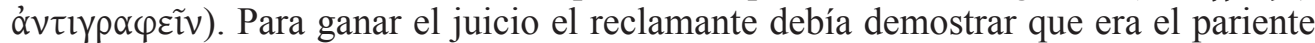
más próximo del difunto o que éste había dejado un testamento auténtico adoptándolo como hijo. Finalmente, según la decisión del jurado, el arconte atribuía la herencia a quien le hubiere correspondido, adjudicación que también recibía el nombre de $\dot{\varepsilon} \pi l-$ $\delta i \kappa \alpha \sigma i ́ \alpha$. Una vez que la herencia había sido legalmente adjudicada, un nuevo reclamante podía reivindicarla en vida del primer heredero o no más de cinco años tras su muerte. Lo cual suscitaba otra diadikasía con la consiguiente alegación escrita (antigraphé) de los implicados ${ }^{6}$. Veamos algunos ejemplos:

A la muerte de Arquíades (D. XLIV) le sucede su hijo adoptivo Leócrates I, que, a su vez, deja en la casa del difunto a un hijo suyo, Leóstrato II, y regresa a su familia de origen. Éste, por su parte, hace lo propio con su hijo Leócrates II, que muere sin descendencia. Entonces Aristodemo, por medio de su hijo (synégoros), reivindica la herencia en su condición de pariente más próximo de Arquíades por vía masculina (nieto de un hermano suyo). Pero se la disputa en una diadikasía Leóstrato II, como

\footnotetext{
${ }^{6}$ Harrison (1968 I: 156-161); MacDowell (1978: 102-103); Todd (1993: 120).
} 
si todavía siguiera siendo hijo adoptivo del difunto Arquíades, del demo de Otrine, y no hubiera vuelto, en realidad, a su casa originaria de Eleusis, perdiendo así todos sus derechos sobre dicho legado.

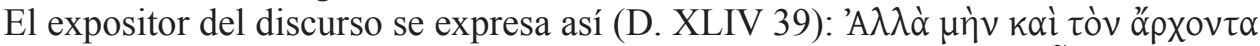

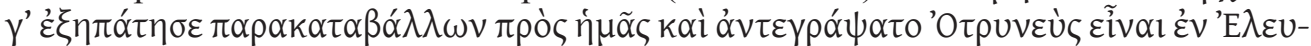

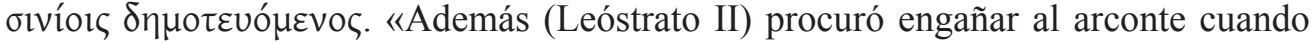
realizaba el depósito ${ }^{7}$ para enfrentarse a nosotros y alegó en el escrito de réplica que era de Otrine, siendo así que era demota de Eleusis» (cf. trad. de J. M. Colubi Falcó).

A la muerte de Comón sin hijos, Calístrato, el expositor del discurso (D. XLVIII), que se consideraba a sí mismo el pariente más próximo, y su cuñado Olimpiodoro suscriben un contrato para repartirse equitativamente su herencia sin contar con el

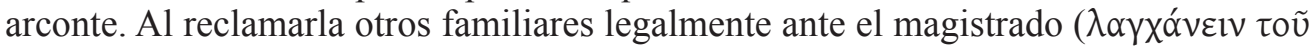

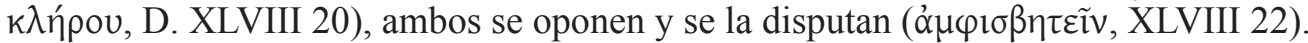
Suscitada la diadikasía, Calístrato pide un aplazamiento por movilización de su cómplice. Habiendo sido denegado por el tribunal, el propio Calístrato, en honor al pacto, renuncia también a su pretensión, por lo que la herencia es atribuida a sus adversarios, de la cual toman posesión. Tras el regreso de Olimpiodoro ambos cómplices promueven otra diadikasía contra los actuales poseedores de la herencia, en la que, actuando cada uno por separado, sale victorioso Olimpiodoro.

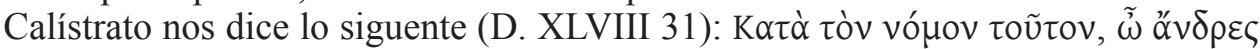

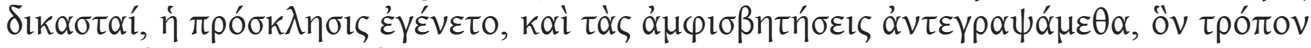

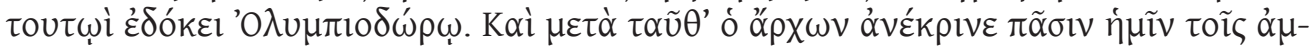

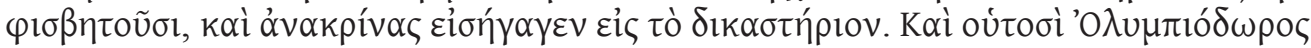

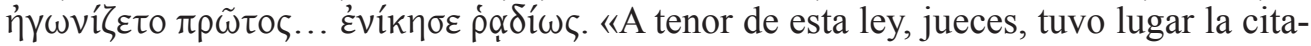
ción, y alegamos en el escrito de réplica en contra de las reivindicaciones del modo que le pareció a Olimpiodoro, aquí presente. A continuación el arconte instruyó el proceso a todos nosotros, los reivindicantes, y después de haberlo instruido introdujo el caso en el tribunal. Olimpiodoro, aquí presente, litigaba el primero... venció con facilidad» (cf. trad. de J. M. Colubi Falcó).

A la muerte de Hagnias (Is. XI) y su hija adoptiva, después de algunos avatares, su herencia fue atribuida en una diadikasía a Filómaca II en virtud del parentesco (hija de primo hermano de Hagnias). Pero, a su vez, se la disputan en una nueva diadikasía la propia madre de Hagnias, que era además prima segunda de su hijo, y Teopompo, el expositor del discurso, también primo segundo de Hagnias, que resultó vencedor.

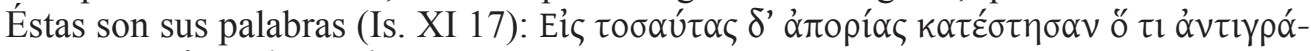

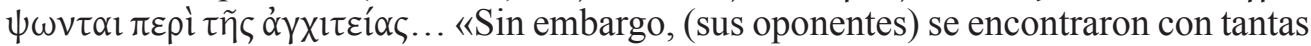
dificultades a la hora de alegar en el escrito de réplica los argumentos respecto a su derecho de sucesión...» (trad. de M. A. Jiménez López).

1.1.2. El segundo tipo de antigraphé, el general, sobre el que escribe Harpocración, está menos estudiado. El demandante, tras emplazar al demandado ante el magistrado competente, el día señalado informaba a este último sobre la demanda con-

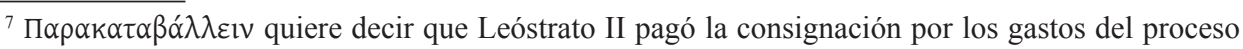
para poder presentar la reclamación. 
tra su oponente. En principio, el informe se comunicaba oralmente y a continuación un funcionario se encargaba de redactarlo. Posteriormente, entrado el s. IV, hacia el $378 / 7$ a.C. se entregaba directamente por escrito ${ }^{8}$. Contra el cargo del demandante el demandado respondía defendiéndose con otro escrito. Según Harpocración, ambas declaraciones, no sólo la contestación del adversario, sino también la notificación del acusador recibían el nombre de antigraphaí: 'escritos de alegación o de réplica' ${ }^{9}$. El discurso Contra Estéfano I de Demóstenes (XLV 46) nos proporciona un buen ejemplo de

\section{АNТІГРАФН}

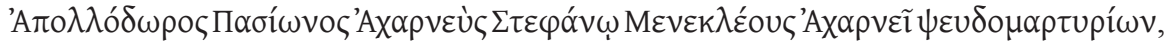

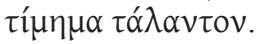

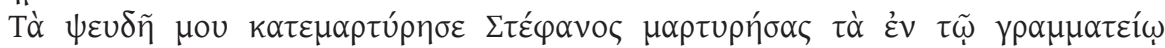

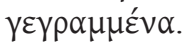

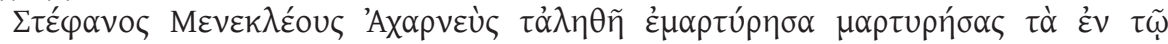

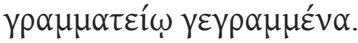

\section{ESCRITO DE RÉPLICA}

«Apolodoro, hijo de Pasión, de Acarnas, contra Estéfano, hijo de Menecles de Acarnas, por falsos testimonios; estimación un talento.

Falso testimonio depuso contra mí Estéfano cuando atestiguó lo escrito en el documento.

Estéfano, hijo de Menecles, de Acarnas: depuse la verdad cuando atestigüé lo escrito en el documento» (trad. de J. M. Colubi Falcó).

1.1.3. Ahora bien, ¿en qué momento del proceso judicial tenía lugar la antigraphé? ${ }^{10}$ En la fase inicial del proceso, cuando los litigantes o reclamantes comparecían por primera vez ante el magistrado el día previsto ${ }^{11}$, antes de la anákrisis o instrucción preliminar. En ese momento el acusador o reclamante presentaba el cargo o reclamación ( $\gamma \rho \alpha \varphi \eta ́)$, puesto por escrito o por un funcionario o por el propio interesado, y su oponente le replicaba también por el mismo procedimiento (đ̊ $v \tau \imath \gamma \rho \alpha \varphi \eta ́)$. Así lo indica claramente el texto D. XLVIII 31 antes expuesto ( $\$ 1.1 .1$.$) . Al mismo tiempo { }^{12}$, para que fuera admitida la demanda los litigantes tenían que pagar unos gastos procesales llamados de forma general $\pi \alpha \rho \alpha k \alpha \tau \alpha \beta \circ \lambda \alpha i ́$ ( $\pi \rho v \tau \alpha v \varepsilon \tilde{\imath} \alpha, \pi \alpha \rho \alpha \sigma \tau \alpha \dot{\sigma} \sigma \varepsilon i \varsigma$ y $\pi \alpha \rho \alpha \kappa \alpha \beta \circ \lambda \alpha i ́$ en sentido específico $)^{13}$. A esta doble circunstancia, antes de la anákrisis, alude la cita de D. XLIV 39 arriba mencionada (§ 1.1.1.): por un lado al depósito de las tasas

\footnotetext{
${ }^{8}$ HARRISON (1971 II: 88).

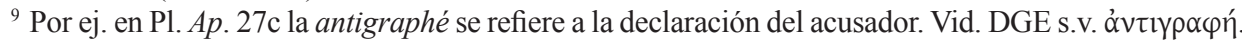

${ }^{10}$ Según Harrison (1971 II), en los comienzos del proceso, antes de la anákrisis (p. 92), pero si se trataba de una diadikasía sobre herencias, durante la anákrisis (p. 100); según MACDowell (1978: 240), siempre en la anákrisis.

${ }^{11}$ Éste es el criterio de HANSEN (19992: 196).

${ }^{12}$ Lipsius (1905-1915: 823 n. 72; 824-825); Ar. Nu. 1131-1200.

${ }^{13}$ HARRISON (1971 II: 92-94, 179).
} 
judiciales ( $\pi \alpha \rho \alpha \kappa \alpha \beta ం \lambda \eta ́)$ de un reclamante en una diadikasia; por otro, a la réplica del mismo a su adversario.

El concepto de antigrahé (§1.1.1.-1.1.2.) es, pues, exactamente el mismo en los dos tipos de casos que diferencia Harpocración.

1.2. Pero Pólux (Poll. 8.58; cf. 8.33) también distingue otros tipos de antigraphaí:

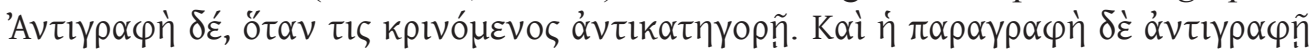

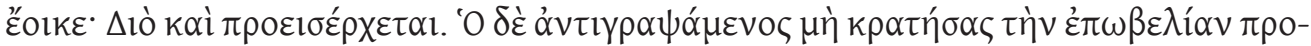

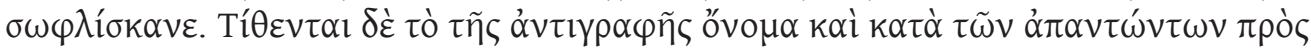

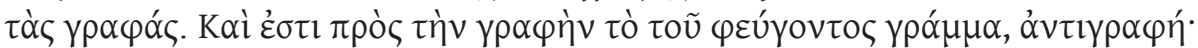

«Escrito de alegación o réplica: cuando uno, al ser juzgado, acusa a su vez. También la excepción se asemeja a un escrito de réplica. Ése es el motivo por el que entra delante (de la acción principal). El que interpuso la excepción, si no vencía, debía además la epobelía (un óbolo por dracma). Dan también el nombre de escrito de réplica en el caso de los escritos que se oponen a las denuncias ${ }^{14}$. Y frente a la denuncia existe el escrito del acusado, el escrito de réplica».

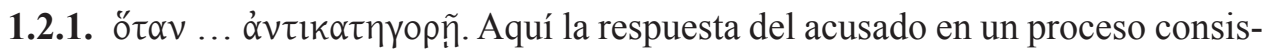
te en emprender otro contra del acusador.

a) Tal acción de réplica puede ser de carácter totalmente distinto a la incoada por el perseguidor. Así, por ej., Cefisio (Lys. VI 42) acusa al impío Andócides mediante una éndeixis, 'delación', por haber violado el decreto de Isotímides (415 a.C.), que prohibía la entrada en el ágora y los templos al autor de actos de impiedad. Es obvio que el pleito que incoe a su vez Andócides no puede ser del mismo tipo, sino de otro diferente. El expositor del discurso, que no es el propio Cefisio,

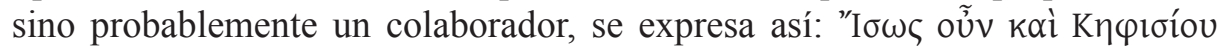

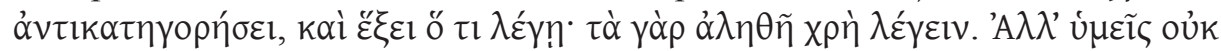

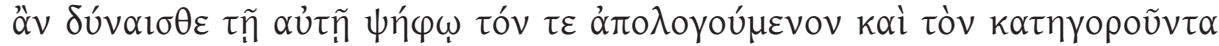

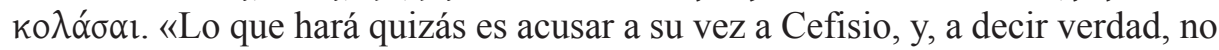
le faltarán cosas de qué hablar; pero vosotros no podéis castigar en la misma votación al que se defiende y al que acusa» (trad. de M. Fernández-Galiano).

Cuando Esquines presentó la rendición de cuentas por su segunda embajada (346/5 a.C.), Demóstenes y Timarco le denunciaron por su mala gestión, sobornado por el dinero de Filipo. Antes de que se celebrara el juicio, Esquines

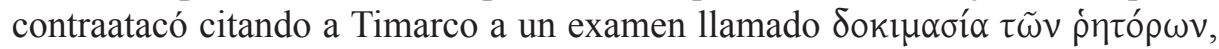
'prueba de idoneidad de los oradores'. Por este procedimiento se juzgaba si un ciudadano había transgredido la ley que prohibía hablar en la Asamblea a quien

${ }^{14}$ En el s. IV a.C., a partir aproximadamente del 378/7 a.C., las denuncias se presentaban por escrito

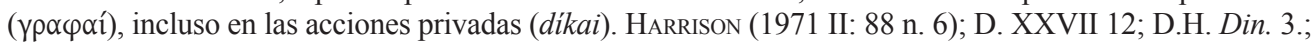
MACDowell (1978: 239). 
llevaba una vida inmoral ${ }^{15}$. He aquí las palabras del orador (Aeschin. I 119) 'O $\delta \eta \mu \eta \gamma o \rho \varepsilon \tilde{\mathcal{L}}$... «Pues bien, cuando precisamente he tomado la determinación de replicar con una acusación a Timarco en el sentido de que, por haberse prostituido, no le era posible hablar en la Asamblea...» (cf. trad. de J. M. Lucas de Dios).

Véase otro ejemplo en Is. VI 52.

b) El pleito de réplica puede ser de idéntico tipo y por el mismo y único motivo que el entablado por el acusador.

El expositor del discurso y Teofemo se acusan mutuamente de haber iniciado una pelea. Aquél emprende entonces contra éste un proceso por golpes ( $\delta i ́ k \eta$

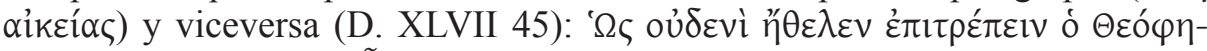

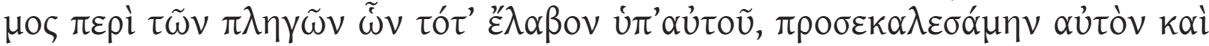

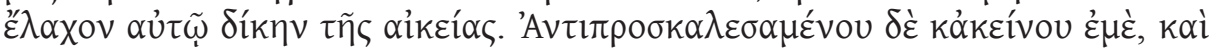

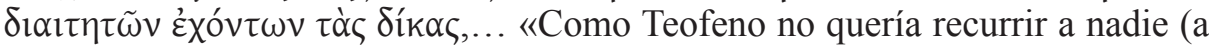
un mediador) en la cuestión de los golpes que en aquel entonces recibí de su mano, le cité a juicio y ejercité contra él una acción por golpes. Habiéndome citado también él y teniendo los árbitros los procesos, ... » (trad. de J. M. Colubi Falcó).

c) La acción de respuesta puede ser de igual tipo por un motivo semejante y paralelo al alegado por su rival.

Mantias estuvo casado dos veces. De Plangon, de la que se divorció y relegó a la condición de concubina, tuvo dos hijos, Mantíteo II (Beoto), concebido antes de la separación, y Pánfilo. De su segunda esposa nació Mantíteo I, considerado inicialmente como su único hijo legítimo. Una vez reconocidos también los dos hijos de Plangon, cuando los tres herederos decidieron repartirse equitativamente la herencia paterna, Mantíteo I reivindica la dote materna del fondo común hereditario, Mantíteo II, a su vez, la de la suya. Entonces Mantíteo II entabla contra su medio hermano Mantíteo I un proceso de interdicción (Jíkn

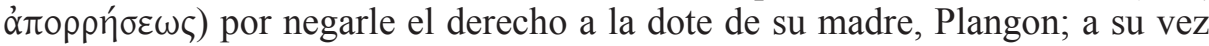
éste contra aquél por impedirle el acceso a la de la suya ${ }^{17}$.

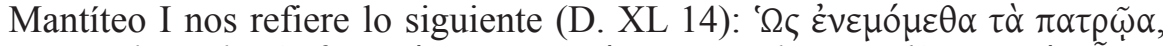

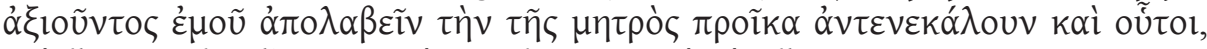

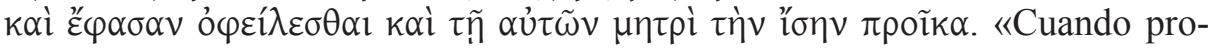
cedíamos a la partición del patrimonio, como pidiera recuperar la dote de mi madre, éstos (Mantíteo II y Pánfilo) formularon una reclamación contraria y dijeron que también a su madre se le debía una dote igual» (trad. de J. M. Colubi Falcó).

Ninguna de las dos acciones llegó a su fin, porque las dos partes se pusieron de acuerdo para revocarlas y dirimir sus diferencias en un arbitraje privado.

\footnotetext{
${ }^{15}$ Cf. Martin - Budé (1927: 14).

${ }^{16}$ LuCAs de Dios (2002: 232 n. 250); vid. Aeschin. I 154, Martin - Budé (1927: 72 n. 1); cf. Aeschin. I 178.

${ }^{17}$ García Domingo (2013:253-258).
} 


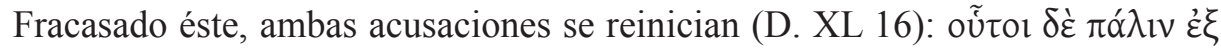

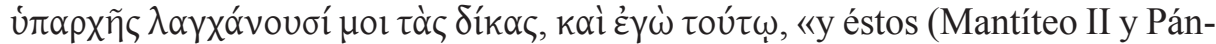
filo) nuevamente ejercitan contra mí las acciones desde el principio y yo contra éste (Mantíteo II)» (trad. de J. M. Colubi Falcó).

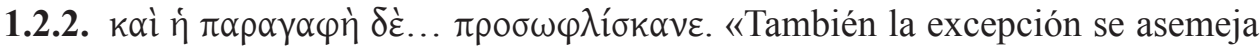
al escrito de alegación... ». Lo único en común de la paragraphé con la antigraphé, tal y como la entiende Pólux al comienzo de su explicación (§1.2.1.), es el hecho de que ambas son acciones de réplica. Por lo demás existen grandes diferencias. La antigraphé, según el lexicógrafo, consistía en una especie de proceso de reconvención con el que el demandado respondía al juicio que el demandante había promovido contra él: ambas acciones eran paralelas e independientes.

En cambio, se llamaba paragraphé a la acción con que el demandado contestaba al demandante por haber emprendido contra él un proceso ilegal. La paragraphé interrumpía y posponía el pleito principal hasta que aquélla se hubiera celebrado. Si la paragraphé prosperaba la acción principal quedaba anulada, en caso contrario esta última continuaba ( $(0$.$) .$

1.2.3. $\tau i ́ \theta \varepsilon v \tau \propto l \ldots$ Aquí Pólux parece referirse de una manera mucho más general al tipo de $\alpha \dot{v} \tau\} \rho \alpha \varphi \eta ́$ al que ha hecho ya alusión Harpocración de forma más detallada (§ 1.1.1.-1.1.2.).

1.3. En resumen, por lo que nos indican Harpocración (§ 1.1.1.-1.1.3.) y Pólux en

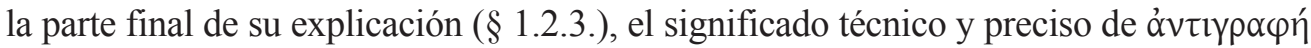
parece ser el siguiente: el escrito de alegación o réplica con que el demandado o reclamante respondía a la acusación o reclamación ( $ү \rho \alpha \varphi \eta ́)$ de su oponente el día en que comparecía ante el magistrado antes de la anácrisis; por extensión se aplicaba también el nombre a la propia acusación o reclamación del demandante.

Según Pólux (§ 1.2.1.), además de este sentido específico y concreto, tenía otro no técnico: la respuesta con que el demandado, mediante una nueva acción incoada por él contra el demandante, replicaba al proceso iniciado por este último.

La antigraphé en sentido no técnico y la paragraphé sólo coinciden, como acabamos de señalar (§ 1.2.2.), en que son acciones de réplica, pero su origen, su funcionamiento, su finalidad y su resolución son distintos.

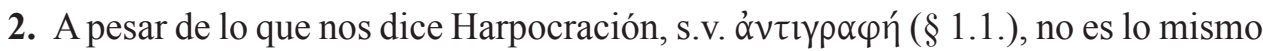

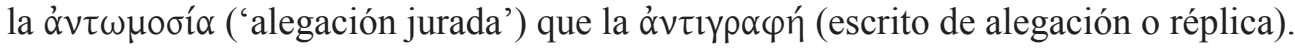

El escrito de réplica se presentaba, como acabamos de indicar, en la fase preliminar del litigio, previa a la instrucción del proceso (anácrisis). En cambio, la declaración jurada tenía lugar durante ésta última, antes de la vista del juicio. Cuando el perse-

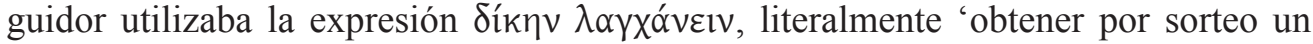
señalamiento para la celebración de un proceso', es decir, 'incoar un proceso', eso 
significaba que el magistrado había fijado un día para la anácrisis, antes de que tuviera lugar la vista del juicio propiamente dicha en fecha posterior ${ }^{18}$.

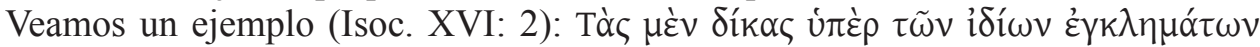

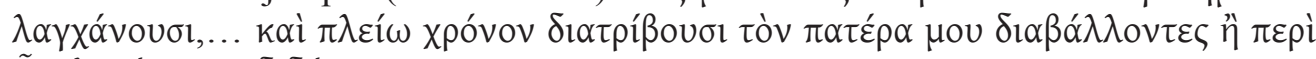

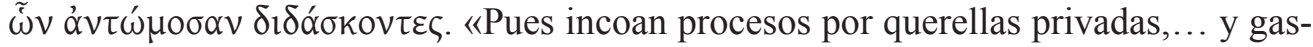
tan más tiempo en calumniar a mi padre que en demostrar lo que alegaron bajo juramento» (trad. de J. M. Guzmán Hermida).

Como más adelante veremos, en una diadikasía sobre herencias, cuando las partes juraban sus respectivas reclamaciones (åv $\tau \omega \mu$ oбíal), una de ellas podía prestar además en apoyo de su reivindicación la declaración testifical ( $\delta$ i $\mu \alpha \rho \tau u \rho i ́ \alpha)$ de que la herencia no era adjudicable porque existía un heredero legítimo. Este testimonio

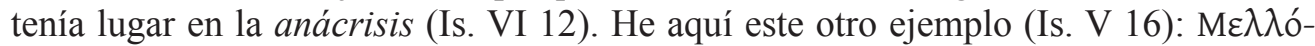

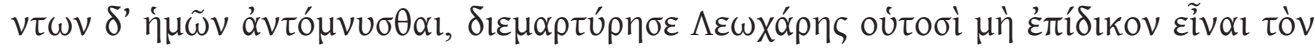

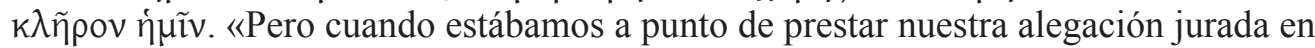
la instrucción preliminar, Leócares, éste de aquí, elevó la protesta testifical de que la herencia no nos podía ser adjudicada judicialmente» (trad. de M. A. Jiménez López).

La confusión entre antomosía y antigraphé, a la que hace referencia Harpocración, tiene su origen, al parecer, en una mala interpretación del siguiente pasaje de Platón

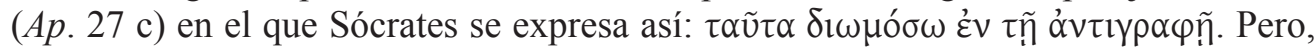
en realidad, Platón no confunde los dos términos. Lo que tenemos aquí es el juramento que, en la anácrisis, el perseguidor (Meleto) prestó en apoyo de su demanda presentada inicialmente (es decir, antes de la anácrisis) contra Sócrates ante el magistrado, juramento que luego se adscribió a ella en esa fase del proceso: «Eso es lo que juraste en la instrucción preliminar en (apoyo de) el escrito de alegación» (§ 3.3.1.).

Igualmente, la glosa correspondiente a $\varepsilon \nu \tau \tilde{n} \dot{\alpha}^{\alpha} \nu \tau \imath \gamma \rho \alpha \varphi \tilde{n}^{19}$, no es pertinente en este

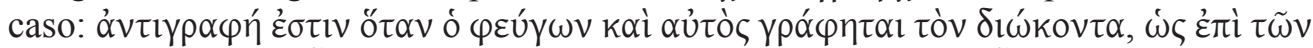

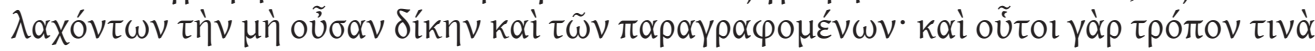

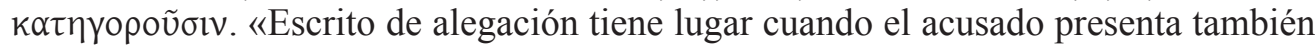
él mismo una denuncia escrita contra su acusador, como en el caso de quienes incoan un proceso contra la sentencia de incomparecencia y de quienes interponen una excepción; pues también ellos en cierta manera acusan».

3.1.1. Vamos a prestar a continuación especial atención a ciertos aspectos del procedimiento judicial ateniense, siguiendo sucintamente los pasos que un ciudadano debía dar para obtener justicia ${ }^{20}$. Como norma (cf. $\S 1.1 .2$.), el perseguidor en presencia de dos testigos ( $(\lambda \lambda \tau \tau \tilde{\eta} \rho \varepsilon \varsigma)$ citaba oralmente ( $\pi \rho o ́ \sigma \kappa \lambda \eta \sigma r \varsigma)$ a su adversario para que se presentara ante magistrado correspondiente el día señalado. En esa fecha el demandante entregaba al citado funcionario la denuncia escrita $\left(\gamma \rho \alpha \varphi \eta ́\right.$ ) ${ }^{21}$; el demandado, a

${ }^{18}$ Cf. Harrison (1971 II: 88-89; 99-100); MacDowell (1978: 239-240).

${ }^{19}$ Chase Greene et alii (1988: 6).

${ }^{20}$ Cf. HARrison (1971 II: 85-105); MacDowell (1978: 237-242).

${ }^{21}$ Hasta aproximadamente el 378/7 a.C. el demandante comunicaba verbalmente la denuncia que un escriba ponía a continuación por escrito. 


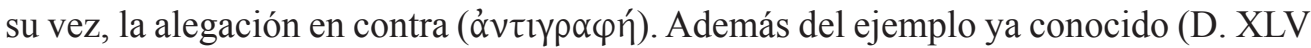
46; § 1.1.2.) podemos poner el siguiente:

El expositor del discurso (D. XLII 17-18) ha sido requerido para prestar un servicio público o liturgia, pero considerando que Fenipo es más rico que él, le propone ante los estrategos para que lo desempeñe en su lugar o intercambie sus propiedades con él (antídosis). Como no hay acuerdo entre ambos, la disputa se resuelve mediante una diadikasía. El expositor del discurso acusa, entonces, a su rival de haber diferido ilegalmente la fecha para la declaración de sus bienes y de haber falseado, entre tanto, el mencionado inventario (D. XLII 1-2, 4, 11-12, 26-30). Fenipo le replica que tampoco él ha respetado el plazo legal: «Fenipo alegó en contra que yo hacía una declaración

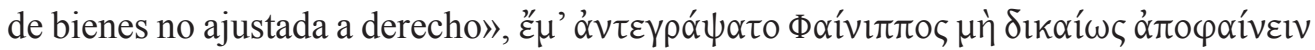

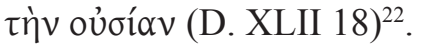

3.1.2. Sin embargo, en las reclamaciones sobre herencias (en las que en general no debemos hablar de acusador ni de acusado, sino simplemente de litigantes ${ }^{23}$ el recla-

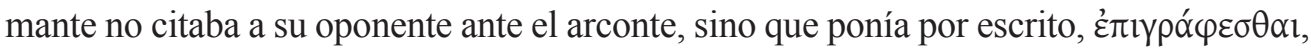
ante el citado magistrado su demanda de adjudicación (Is. III 30, 32; IV.2, 4). Si éste le otorgaba por sorteo un señalamiento para la adjudicación de la herencia, $\kappa \lambda \eta \rho \circ \tilde{v} v$

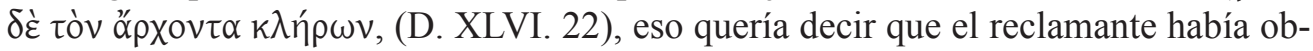

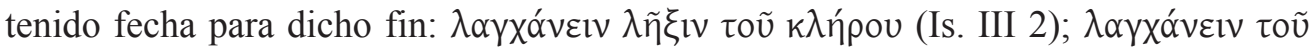
$\kappa \lambda$ ńpou (Is. III 30, 32, 57, 58, etc.). El giro significa literalmente 'obtener por sorteo un señalamiento para la adjudicación de la herencia', que en la practica se suele traducir por 'reclamar la herencia'.

Pero ocurría que el arconte, antes de proceder a la asignación en el día indicado, remitía 'los señalamientos por sorteo para las adjudicaciones de las herencias' o 'las

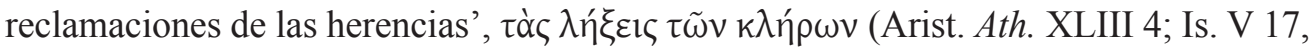
III 43), a la Asamblea, en donde en la reunión principal de cada pritanía (кupía) eran leídos por si alguno tenía intención de disputar con el interesado la adjudicación de

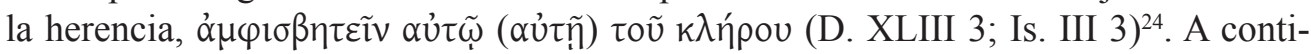
nuación en dicha sesión el heraldo proclamaba en voz alta «si alguno quería disputar o efectuar el depósito por la herencia (de Fulano) por razones de parentesco o de

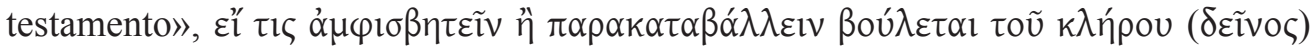

22 Véase al respecto García Domingo (2013: 280-284), en donde, sin embargo, se sitúa el escrito de alegación de Fenipo en la anácrisis de acuerdo con lo que a veces se ha pensado (§ 1.1.3. n. 10), y no antes de la misma.

${ }^{23}$ Cf. Harrison (1968 I: 158-160); MacDowell (1978: 102-103); Todd (1993: 120).

${ }^{24}$ Aristóteles (ibídem) nos dice lo siguiente: «En una (asamblea), en la principal, en la que... deben leerse los señalamientos por sorteo para las adjudicaciones de las herencias y de las hijas herederas, para que a nadie pase inadvertido que algo quedó vacante». De esta manera no serían válidos pretextos como éstos (Is. III 45): «Con respecto a la adjudicación de la herencia ( $\dot{\pi} \pi \_$$\left.\delta \alpha \sigma i ́ \alpha\right)$, ciertamente alguien podría alegar ante vosotros una falsa excusa: Nicodemo podría fingir que ellos no se enteraron» (cf. trad. de M. D. Jiménez López). 


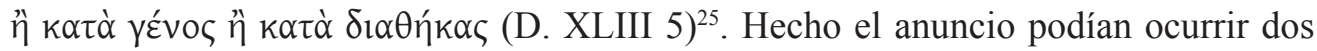
situaciones:

a) El día establecido se presentaba solamente el único que había obtenido el se-

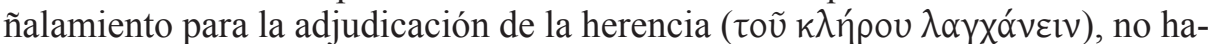

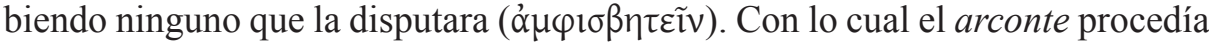
directamente a su adjudicación judicial (epidikasía) ${ }^{26}$. Actuaba así basándose en la antigua capacidad que tenía el arconte de juzgar por sí mismo ( $\alpha u ̉ \tau o \tau \varepsilon \lambda \eta ́ \varsigma)^{27}$.

Examinemos el siguiente caso (Is. III 43-44). Al morir Pirro, su hijo Endio, adoptado por testamento, reclamó judicialmente la herencia, que le fue adjudicada sin oposición. Pero Nicodemo, cuñado de Pirro, afirmó que Endio lo hizo sin tener en cuenta para nada a File, la hija de Pirro y su legítima esposa, la hermana de aquél. He aquí las palabras del expositor del discurso, el

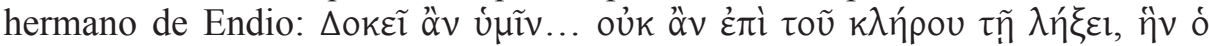

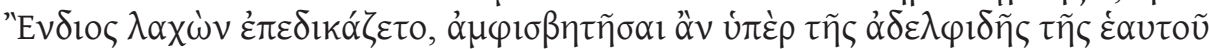

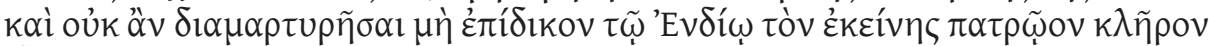

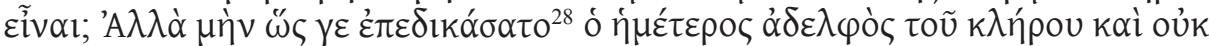

${ }^{25} \Pi \alpha \rho \alpha \kappa \alpha \tau \alpha \beta \alpha ́ \lambda \lambda \varepsilon ı v$ se utiliza cuando un nuevo reivindicante paga la consignación antes de la instrucción preliminar (anácrisis) para participar en el proceso de adjudicación judicial de la herencia (diadikasía)

'A $\mu \varphi \imath \sigma \beta \eta \tau \varepsilon \tilde{i} v$ se emplea, en general, cuando un nuevo reivindicante disputa la herencia a quien reclama su atribución judicial (epidikasía), sin implicar que necesariamente vaya a participar en el proceso de adjudicación judicial (diadikasía). Por eso a veces es menester precisar de algún modo esta última idea, como en este caso: 'disputar o efectuar un depósito'. Evidentemente, si el reivindicante no quiere entrar en la diadikasía, no tiene que pagar la consignación.

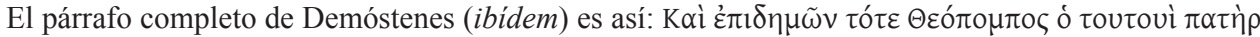

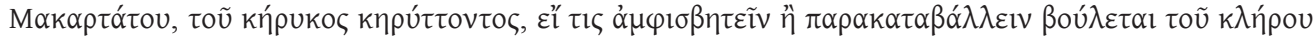

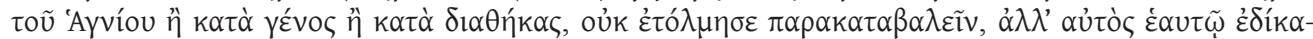

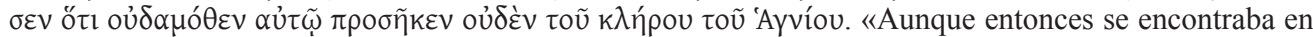
Atenas Teopompo, el padre de este Macártato, cuando el heraldo proclamó si alguien quería disputar o efectuar el depósito por la herencia de Hagnias por razones de parentesco o de testamento, no tuvo valor para hacer el depósito, sino que, para sí mismo, juzgó él que de ningún lado le asistía derecho a nada de la herencia de Hagnias» (cf. trad. de J. M. Colubi Falcó).

Aunque, por estar en Atenas, se supone que Teopompo en la citada reunión de la Asamblea se enteró de que Filómaca II, como pariente más próxima, reclamaba judicialmente la herencia de Hagnias, éste no se atrevió a hacer el depósito ante el arconte antes de la instrucción preliminar (anácrisis) para poder tomar parte en el proceso de adjudicación de la herencia (diadikasía), porque sabía que no le correspondía. La proclama se daba a conocer en la Asamblea, pero obviamente la entrega del dinero tenia lugar ante el citado magistrado.

${ }^{26}$ Lo mismo pasaba en una diadikasía, de la que hablaremos a continuación, si en la anácrisis solo comparecía uno de los reclamantes, HaRRISON (1971 II: 102).

${ }^{27}$ Cf. Harrison (1971 II: 4); MaCDowell (1978: 26). La cuestión es objeto de controversia. Algunos piensan que el tribunal de justicia también aquí debía reunirse para adjudicar formalmente la herencia al único solicitante. Sin embargo, contra esta hipótesis se puede argumentar que sería absurdo (además de nada rentable) convocar un tribunal cuando no existen litigantes. Sobre esta discusión véase RUBINSTEIN (1963: 40).

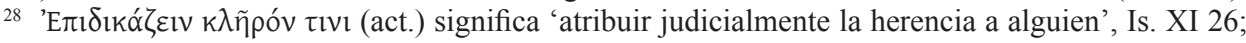

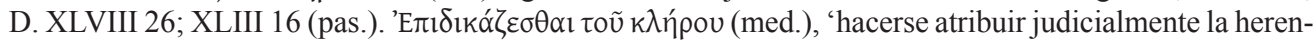
cia', 'obtener la adjudicación judicial de la herencia', Is. III 41, 69; V 40; D. XLIII 3. Véase, no obstante, HARRISON (1968 I: 11 n. 1). 


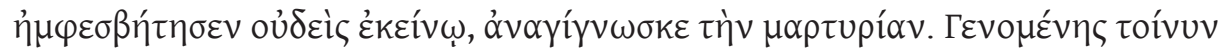

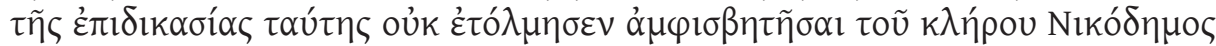

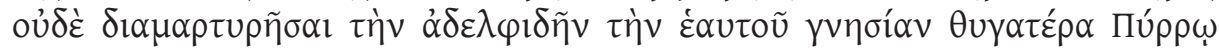
$\kappa \alpha \tau \alpha \lambda \varepsilon l \varphi \theta \tilde{\eta} v \alpha$. «¿Os parece que... en el señalamiento por sorteo que obtuvo Endio para la adjudicación de la herencia, Nicodemo no la habría disputado en nombre de su sobrina y no habría protestado con testigos que la herencia paterna de ella no podía ser atribuida judicialmente a Endio? Pero da lectura al testimonio según el cual mi hermano obtuvo la adjudicación judicial de la herencia y nadie la disputó con él. Pues bien, cuando tuvo lugar esta adjudicación judicial, Nicodemo no se atrevió a disputar por ella, ni a protestar con testigos que su sobrina había sido dejada por Pirro como hija legítima».

b) También podía suceder que el día señalado mediante sorteo por el arconte, además del que había reclamado la asignación judicial de la herencia, acudiera alguno o algunos que la disputaran. Éste o éstos presentaban entonces su alegación escrita en contra (antigraphé, D. XLIV 39). Es evidente que en tales circunstancias el arconte no podía otorgar directamente la asignación de la herencia (epidikasía) a quien la había solicitado al principio, sino a quien de ellos le correspondiera tras un proceso de adjudicación judicial (diadikasía, D. XLIV 7, 40). Después de la instrucción preliminar (anácrisis) el arconte introducía la disputa en el tribunal el día que había sido señalado. Una vez celebrado el debate los jueces votaban y, según el resultado de la votación, el citado magistrado, en presencia del tribunal, procedía a la asignación de la herencia (epidikasía) a quien le había correspondido (D. XLVI 22; XLVIII 23, 25, 26; Arist. Ath. LVI 6).

Los discursos D. XLIV y XLVIII ya aludidos (§ 1.1.1.) nos sirven de ejemplo.

3.1.3. No obstante, cuando un nuevo reivindicante disputaba una herencia que había sido ya atribuida a un heredero ${ }^{29}$, aquél era considerado como un demandante y seguía el procedimiento habitual de citación del adversario, $\pi \rho \sigma_{\sigma} \kappa \lambda \eta \sigma \iota$, , arriba descrito $(\S 3.1 .1 .)^{30}$. Después de la convocatoria el arconte recibía las alegaciones

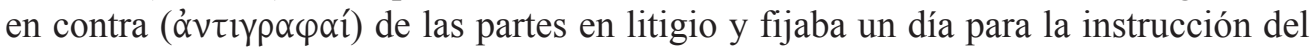
proceso, anácrisis (D. XLVIII 31; Is. XI 17). Se decía entonces que el nuevo reivindicante obtenía del citado magistrado un señalamiento por sorteo para iniciar el proceso

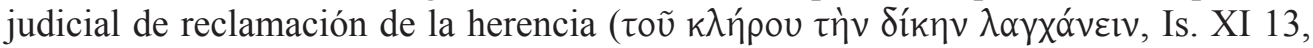

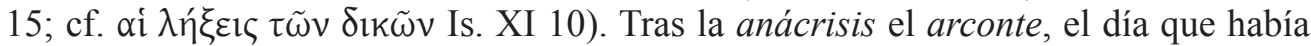

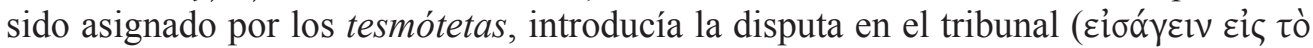

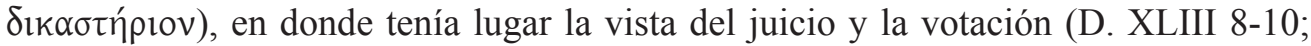
XLVIII 31).

Nos ilustran al respecto los discursos Is. XI y D. XLVIII ya mencionados (§ 1.1.1.).

${ }^{29}$ Los herederos a quienes se había atribuido previamente la herencia podían ser varios (D. XLVIII 29-31), igual que los reivindicantes (Is. XI 10, 16; D. XLIII 6-7; XLVIII 29-31).

30 D. XLIII 7, 15, 16; XLVIII 29; vid. Harrison (1968 I: 160-161); MacDowell (1978: 103). 
3.2.1. Admitida la demanda, el demandante tenía que hacer frente a veces a los gastos procesales llamados genéricamente $\pi \alpha \rho \alpha \kappa \alpha \tau \alpha \beta \beta \lambda \eta ́$ (depósito), y concretamen-

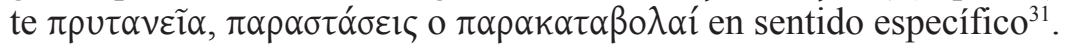

Nos vamos a fijar a continuación en este último tipo de tasa judicial, la parakatabolé o fianza que depositaba quien desafiaba en un contencioso (diadikasía) la adjudicación de la herencia. Dicha consignación consistía en una décima parte de la fortuna en litigio y pasaba probablemente no al Estado, sino a la parte contraria, si quien la disputaba perdía el juicio ${ }^{32}$.

Hay indicios para suponer que dicha suma debía ser pagada al inicio de la diadikasía, cuando los contrincantes presentaban sus alegaciones ante el arconte, antes de la anácrisis (§1.1.3.). A la cita D. XLIV 39 ya aludida, suficientemente ilustrativa

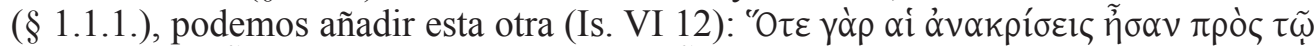

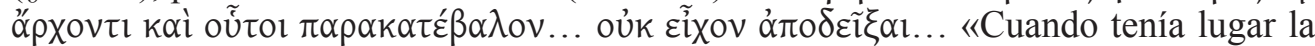
instrucción del proceso ante el arconte y (nuestros adversarios) hubieron depositado la fianza... (nuestros adversarios) no eran capaces de indicar (quién era la madre de los supuestos hijos legítimos de Euctemón)».

3.2.2. Como hemos señalado ( $§ 3.1 .2$. n. 25), $\alpha \mu \varphi \imath \_\beta \eta \tau \varepsilon \tilde{v} v$ se utiliza cuando un reivindicante disputa la herencia a quien la reclama judicialmente o a quien le ha sido adjudicada ya, sin que eso signifique que vaya a suscitar obligatoriamente una

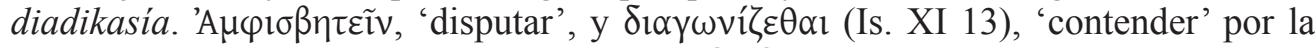

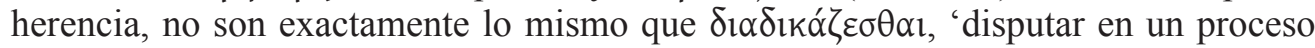
contencioso por la adjudicación de la herencia'. Por ello a veces los autores griegos

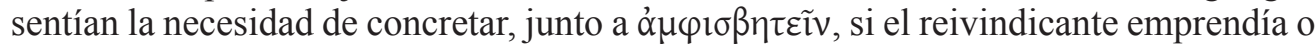
no la diadikasía, aludiendo al pago de la consignación o a algún momento de la anácrisis. Veamos algunos ejemplos:

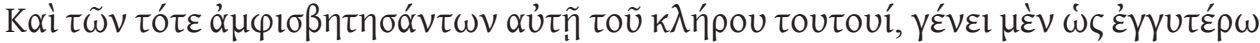

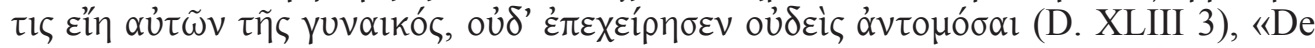
quienes disputaron con ella (Filómaca II) entonces por esa herencia, ninguno intentó prestar la alegación jurada de que era pariente más próximo que la mujer» (cf. trad. de J. M. Colubi Falcó). Lo cual parece sugerir que, como la alegación jurada (antomosía) tenía lugar en la anácrisis (§ 2.), los citados querellantes, aunque en principio disputaron por la herencia, no llegaron a intervenir en la diadikasia propiamente dicha.

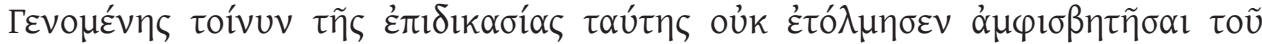

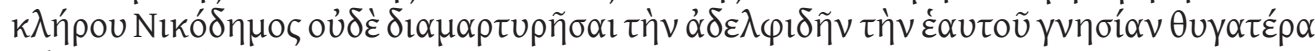
Пú $\rho \omega k \alpha \tau \alpha \lambda \varepsilon l \varphi \theta \tilde{\eta} v \alpha l$ (Is. III 44). «Pues bien, cuando tuvo lugar esta adjudicación judicial de la herencia, Nicodemo no se atrevió a disputar por la herencia ni a atestiguar en una protesta que su sobrina había sido dejada por Pirro como hija legítima». Aquí no hubo disputa de ningún tipo, ni sin diadikasía, ni con diadikasía (diamartyría).

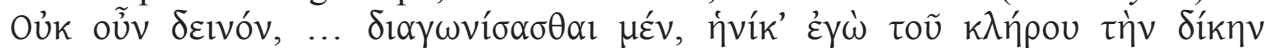

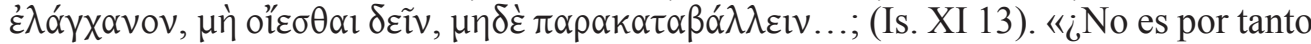
indignante que... cuando yo intentaba un proceso por la herencia, no haya considerado

${ }^{31}$ Harrison (1971 II: 92-94, 179). Vid. § 1.1.3.

${ }^{32}$ Cf. Harrison (1971 II: 181-183); MacDowell (1978: 244). 
preciso contender, ni efectuar el depósito...?» (cf. trad. de M. D. Jiménez López). Este caso es similar al anterior.

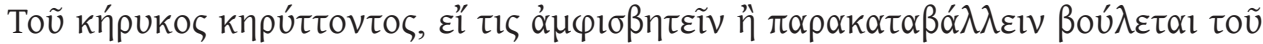

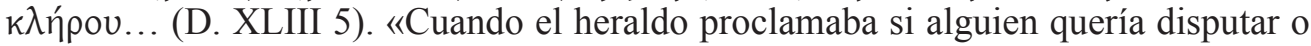
efectuar el depósito por la herencia...», es decir, 'si uno deseaba disputar por la herencia sin contender en una diadikasía o entablándola'. Más adelante en este mismo párrafo se nos indica que Teopompo no efectuó el depósito por la herencia de Hagnias (esto es, no emprendió la diadikasía), pero eso no significa que de algún modo no

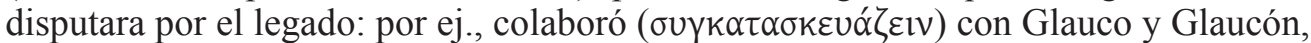
que, habiendo suscitado la diadikasía, presentaron un testamento falso, y depuso en su favor falsos testimonios (D. XLIII 4).

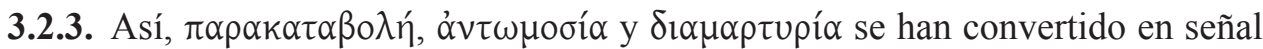
de que la diadikasía ha comenzado. Pongamos un ejemplo (cf. § 1.1.1.).

Al quedar la casa de Arquíades sin descendientes directos, Aristodemo, nieto de su hermano, solicitó al arconte la atribución de la herencia como pariente más próximo. Pero se la disputan en una diadikasía Leóstrato II y Leócares (hijo biológico de este último) como supuestos hijos adoptivos de Arquíades (D. XLIV 42, cf. 52): Kaì

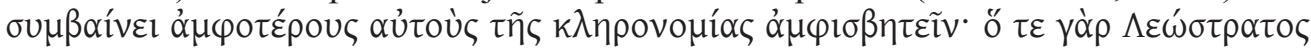

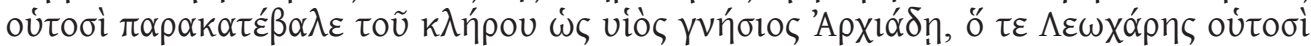

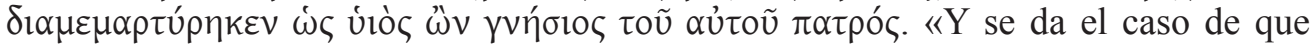
ambos disputan por la atribución de la herencia: en efecto, Leóstrato, aquí presente, efectuó el depósito a título de hijo legítimo de Arquíades y el también presente Leócares ha atestiguado en la protesta que es hijo legítimo del mismo padre (Arquíades)» (cf. trad. de Colubi Falcó).

3.3.1. Durante la anácrisis tenía lugar la ơv $\tau \omega \mu o \sigma i ́ \alpha$. Consistía ésta en el juramento o declaración jurada que pronunciaban las partes litigantes en un pleito o los reivindicantes en una diadikasía para ratificar la veracidad de sus declaraciones (en general, antigraphai) que habían formulado ante el magistrado antes de la instrucción preliminar. Este juramento se adjuntaba luego a estas afirmaciones previas como sugiere el texto antes citado de Platón, $A p .27 \mathrm{c},(\S 2$.) y el siguiente de Diógenes

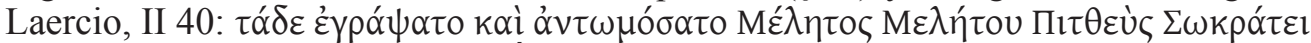
$\Sigma \omega \varphi \rho o v i ́ \sigma \kappa o v ~ ' A \lambda \omega \pi \varepsilon \kappa \tilde{\eta} \theta \varepsilon v$ '... «Ésta es la acusación que formuló por escrito y juró en la instrucción preliminar Meleto, hijo de Meleto, contra Sócrates, hijo de Sofronisco de Alópece:...».

El hecho de que las alegaciones de las partes en disputa (antigraphai) fueran ya conocidas por haber sido formuladas previamente ante el magistrado, explica que en la anácrisis, antes de que fueran ratificadas mediante juramento (antomosía) por los reivindicantes, uno de ellos se adelantara a presentar una protesta testifical (diamartyría), como sucede en Is. V 16 (§ 2.). La protesta testifical se presentaba normal-

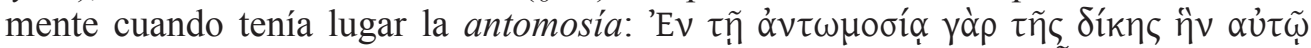

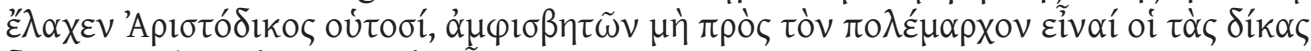

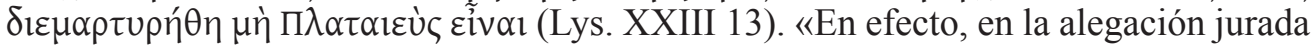
de la parte contraria del proceso que le entabló Aristódico, aquí presente, a pesar de 
que Pancleón disputaba que no le correspondía el que le fuera instruido un proceso ante el polemarco, fue objeto de la protesta testifical de que no era plateense» (cf. trad. de L. Gil).

3.3.2.1. La $\delta 1 \alpha \mu \alpha \rho \tau u \rho i \alpha^{33}$ es, originariamente, la objeción o protesta testifical, presentada durante la antomosía por un litigante a través de un testigo, de que una acusación o reclamación no es legalmente admisible. La fecha de los dos ejemplos más tempranos de este procedimiento oscila en torno al 400 a.C. En el primero de ellos suscita la diamartyría el perseguidor, en el segundo el acusado.

En Lys. XXIII 13 (cf. § 3.3.1.) Aristódico incoó contra Pancleón una acción por un motivo que no conocemos. Aquél, suponiendo que no era ciudadano ateniense, formuló la acusación ante el polemarco, pero Pancleón alegó que era plateense (los plateenses eran a la sazón ciudadanos atenienses), motivo por el que el polemarco no era competente en este asunto, sino un magistrado distinto. Entonces Aristódico por medio de un testigo elevó la protesta (diamartyría) de que no era plateense. Pancleón atacó ( $\left.\dot{\pi} \pi \_\kappa \eta ́ n \tau \varepsilon \sigma \theta \alpha l\right)$ al testigo, pero finalmente no le persiguió por falso testimonio. En consecuencia, el polemarco continuó con la acción original interrumpida por la impugnación de Pancleón, que finalmente perdió el litigio.

En Isoc. XVIII 11-12 y 15 Calímaco persigue al expositor del discurso por deberle supuestamente 10.000 dracmas. Pero éste objeta por medio de un testigo (diamartyría) que la acción es inviable porque la disputa ha quedado ya zanjada gracias a un arbitraje privado. Calímaco no persiguió al testigo por falsos testimonios, sino que retiró la denuncia.

Estos dos pasajes nos permiten sacar las siguientes conclusiones. En el caso de que la diamartyría no fuera desafiada, si ésta procedía del acusador, la acción principal continuaba; si venía del acusado, dicha acción quedaba anulada. En el caso de que la diamartyría fuera impugnada mediante un proceso por falsos testimonios, el magistrado paralizaba la acción principal hasta que aquélla se resolviera. Cuando tenía lugar el juicio por falso testimonio, el que presentaba la diamartyría se convertía en el acusado y el que la impugnaba en el acusador. El resultado del citado proceso decidía si la acción principal debía continuar o no. En el primer ejemplo, si el acusado era condenado, la acción principal quedaba anulada; si era absuelto, la acción principal proseguía. En el segundo ejemplo ocurría lo contrario. Invalidada la acción originaria, dependía de la naturaleza de la disputa el que el perseguidor pudiera incoar otro proceso. En la primera circunstancia era posible hacerlo, emprendiendo la acción ante otro magistrado; en la segunda, de ninguna manera: aquí la victoria del testigo en la acción por falso testimonio ponía fin, al mismo tiempo, al litigio originario.

Como hemos señalado al principio de este estudio ( $\$ 0$.), un nuevo procedimiento, la paragraphé, creado hacia el 400 a.C. por Arquino para perseguir a quienes desafiaban la amnistía del final de la guerra civil (403 a.C.), extendió pronto su ámbito para abarcar casos como los expuestos. A diferencia de la diamartyría, la paragraphé desembocaba automáticamente en un nuevo juicio con los papeles invertidos y paralizaba la acción principal hasta que aquél se resolviera. Sin embargo, no hay constancia

${ }^{33}$ Cf. Harrison (1971 II: 101, 124-131. MacDowell (1978: 212-214). 
de que la paragraphé haya sido utilizada en querellas sobre herencias, donde, según veremos, la diadikasía permaneció como norma ${ }^{34}$.

3.3.2.2. En los casos hasta ahora analizados hemos observado cómo, cuando un litigante interponía una protesta por medio de testigos (diamartyría), su adversario tenía la posibilidad de perseguir al testigo por falso testimonio. Sin embargo, por las diadikasíai sobre herencias sabemos que dicha acción también podía ir dirigida contra el que propiamente presentaba la protesta, además de contra el testigo ${ }^{35}$. Pongamos ahora ejemplos de uno u otro tipo a propósito de tales disputas:

a) El difunto Menecles había dejado un hijo adoptivo en vida, a quien correspondía la herencia. Pero se la disputa en una diadikasía el hermano de Menecles. Entonces el heredero presenta un testigo (Filónides, su suegro) de que existía un hijo legítimo, él mismo. El hermano de Menecles emprende una acción por falso testimonio contra el testigo, a quien defiende el hijo adoptivo con estas

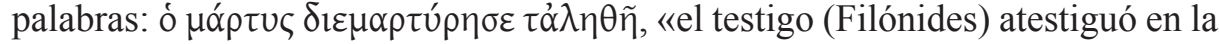
protesta la verdad» (Is. II 2; vid. Is. II 1-2, 44-47).

b) Diceógenes III presentó un primer testamento en el que Diceógenes II le nombraba hijo adoptivo con un tercio de la herencia. Pasados algunos años volvió a mostrar otro, en sustitución del anterior, en que aparecía como heredero universal. Los sobrinos de Diceógenes II lograron condenar por falso testimonio a los testigos que apoyaron el segundo testamento, quedando así la herencia de Diceógenes II intestada. Abierta, pues, de nuevo la disputa legal por la atribución de su fortuna, los sobrinos del difunto la reclaman, pero Diceógenes III hizo comparecer, en una diamartyría, a Leócares como testigo de su adopción. Los parientes llevaron entonces a juicio al testigo por falso testimonio, aunque finalmente la sentencia no llegó a pronunciarse, al alcanzar un acuerdo las partes. El expositor del discurso, uno de los primos, nos refiere lo siguiente:

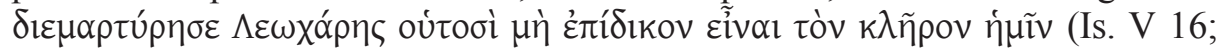
vid. 15-18). «Leócares, éste de aquí, atestiguó en la protesta que la herencia no nos podía ser adjudicada - porque existía un hijo adoptado por testamento, Diceógenes III-» (cf. trad. de M. D. Jiménez López).

c) Al morir sin descendencia Endio, el hijo adoptivo de Pirro por testamento, se apoderó de la herencia de Pirro la hermana de este último en su condición de pariente más próximo del mismo, no como madre de Endio. A su vez Jenocles, esposo de File, supuesta hija legítima de Pirro, intentó arrebatarla (Is. III 22), pero finalmente optó por la vía legal: reclamó en su nombre la herencia de su

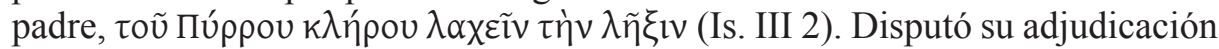
$(\dot{\alpha} \mu \varphi \imath \sigma \beta \eta \tau \varepsilon \tilde{\imath} v$, Is. III 5) la hermana de Pirro, representada por su otro hijo, hermano de Endio. Pero entonces Jenocles elevó la protesta ( $\delta 1 \alpha \mu \alpha \rho \tau u \rho \varepsilon \tilde{v}$, Is. III 3), por medio de un testigo (Nicodemo, tío materno de File, Is. III 4-5), de que la

${ }^{34}$ Todd (1993: 136-137)

${ }^{35}$ En tales disputas la objeción que interponía el reclamante consistía en que la herencia no era adjudicable porque existía un hijo legítimo del difunto. 
herencia de Pirro no podía ser adjudicada a la hermana de este último y madre de Endio, porque existía una hija legítima de Pirro, File. El hermano de Endio emprendió una acción por perjurio contra Jenocles, considerándole responsable del falso testimonio que prestó su testigo, y obtuvo su condena, con lo que la herencia fue asignada a la hermana de Pirro y madre de Endio, que la tenía ya en posesión. Ahora con otra acción por falso testimonio intenta también conseguir la condena de Nicodemo, el testigo de que se sirvió Jenocles en su diamartyría (Is. III 4-6).

d) Filoctemón, hijo de Euctemón, tras haber adoptado por testamento a Queréstrato, murió en vida de su padre. Fallecido también Euctemón sin dejar hijos varones vivos, reclamó toda su herencia su nieto Queréstrato, el mencionado hijo adoptivo del difunto Filoctemón. Pero Androcles, pariente próximo de Euctemón, se la disputó y por medio de un testigo, probablemente su compinche Antidoro (Is. VI 39, 47), interpuso la protesta ( $\delta 1 \alpha \mu \alpha \rho \tau \cup \rho \varepsilon \tilde{\imath} v)$ de que la fortuna de Euctemón no estaba sujeta a adjudicación judicial, porque éste había dejado dos hijos legítimos, nacidos de un segundo matrimonio con Cálipe, de los que él era tutor. Queréstrato contestó directamente a Androcles con una acción por falso testimonio (Is. VI hyp.; VI 3-4; 10-16).

3.3.2.3. Pues bien, estos ejemplos demuestran que tan responsable era el que interponía la diamartyría, como quien prestaba el testimonio propiamente dicho. Ambos podían ser acusados de falso testimonio. Lo mismo pasaba en caso de homicidio,

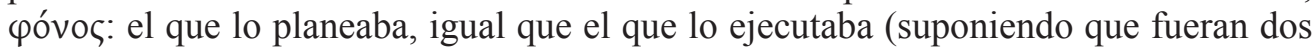

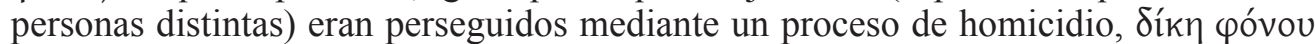
(And. I. 94).

Así, hemos visto ( $\$ 3.3 .2 .2$ a, b.) que a veces el testigo era considerado como si fuera realmente el auténtico promotor de la diamartyría (Is. II 2; V 16). Es evidente que en tales contextos $\delta 1 \alpha \mu \alpha \rho \tau u \rho \varepsilon ́ \omega$ no puede significar ya 'elevar o interponer una protesta por medio de testigos', sino simplemente 'atestiguar en una protesta'.

Pero otras veces también sucedía lo contrario, que el promotor de la diamartyría era considerado como si fuera el testigo directo que prestó el testimonio. Así ocurrió en el caso de Jenocles. Éste, aunque fue quien suscitó la protesta, es llamado

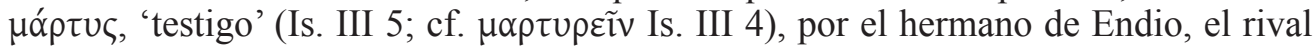
que consiguió su condena en una acción por falso testimonio. Es decir, es calificado lo mismo que Nicodemo, el testigo directo de la citada diamartyría, a quien ahora está persiguiendo en otra acción similar el hermano de Endio, que se expresa así (Is. III 6):

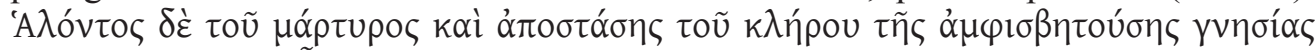

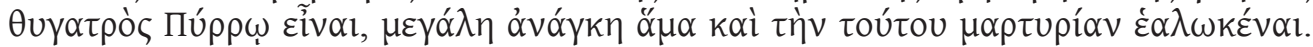
«Sin embargo, puesto que el testigo (Jenocles) fue condenado y la que disputaba ser hija legítima de Pirro desistió de la herencia, es de absoluta necesidad que obtenga también su condena el testimonio de éste (Nicodemo)».

Entonces, si Jenocles es denunciado como si fuera el testigo directo de la diamar-

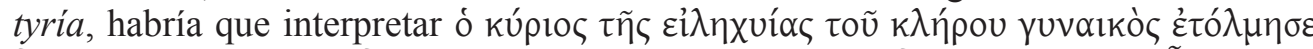

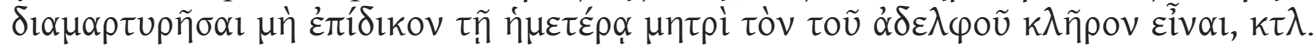
(Is. III 3), «el representante de la mujer que ha reclamado la herencia (Jenocles) se 
atrevió a atestiguar en la protesta que la herencia de su hermano no podía ser adjudicada judicialmente a nuestra madre, etc.» de esta manera y no de esta otra «... se atrevió a interponer la protesta, por medio de un testigo, de que la herencia...».

3.3.2.4. En fin, si el promotor de la diamartyría puede actuar igualmente como si fuera el testigo (§ 3.3.2.3.), y viceversa (§ 3.3.2.2 a, b.), es ya innecesaria la dualidad promotor/testigo y, en consecuencia, el impulsor de la diamartyría puede desempeñar ambas funciones al mismo tiempo. Quien suscita la diamartyría se convierte así también en testigo de su propia causa.

Veamos el siguiente caso (D. XLIV, Contra Leócares). Aristodemo reclama la herencia de Arquíades como pariente más próximo, pero se la disputa en una diadikasía Leóstrato II, como supuesto hijo adoptivo de Arquíades. Puesto que a éste no le fue reconocida tal condición, adoptó entonces irregularmente en calidadad de hijo póstumo de Arquíades a su propio hijo Leócares, que, continuando el litigio, presentó la protesta testifical de que él era hijo legítimo de Arquíades - es decir, atestiguó en su propia causa- (D. XLIV 41-42, 46-48). A consecuencia de ello Aristodemo, por medio de su hijo, acusó a Leócares de falso testimonio (D. XLIV 1-2, 45, 60).

Por la citada acción de que ambos emprenden contra Leócares, estamos informados de lo siguiente: a) que Leócares ha suscitado la diamartyría (D. XLIV 42); b) que Leóstrato II, padre de Leócares, no es el testigo de la diamartyría: aunque era la persona idónea para comparecer en ella y dar testimonio de los hechos anteriores a la adopción y de la propia adopción de Leócares, rehuyó esa responsabilidad (D. XLIV 55-56); c) que en su lugar ha actuado como testigo el propio Leócares, el instigador de la diamartyría, atestiguando hechos falsos, ni siquiera conocidos por él (D. XLIV 54-

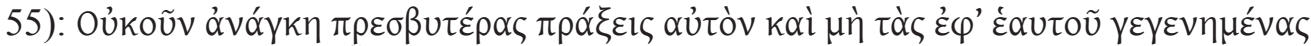

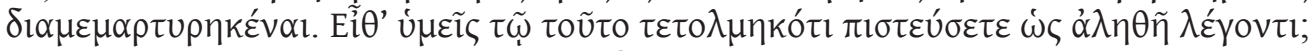

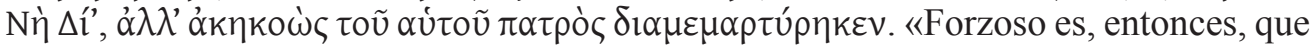
Leócares en la protesta haya atestiguado hechos más antiguos y no los sucesos de su tiempo. ¿Conque creeréis vosotros a quien se ha atrevido a eso, presumiendo que dice la verdad? ¡Por Zeus!, es que lo ha atestiguado en la protesta por habérselo oído a su padre».

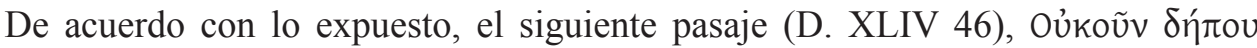

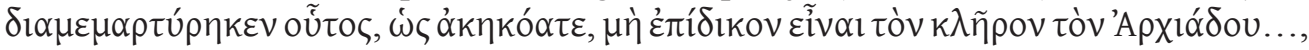
debería interpretarse así: «Entonces éste (Leócares) sin duda, como habéis oído, ha atestiguado en la protesta que la herencia de Arquíades no está sujeta a adjudicación judicial...», en lugar de «ha elevado por medio de testigos la protesta de que...». La traducción propuesta refleja que el autor y el testigo de la diamartyría son la misma persona $^{36}$.

3.3.2.5. En resumen, la $\delta 1 \alpha \mu \alpha \rho \tau u p i ́ \alpha$ (cf. $\S 3.3 .2 .1$.) es la objeción o protesta testifical presentada durante la antomosía por un litigante, bien a través de un testigo (Lys. XXIII 13; Is. III 5, 6; VI hyp., 52), bien directamente actuando él mismo como

${ }^{36}$ Vid. Gernet (1957 II: 129, D. XLIV 42; 147 n. 2, XLIV 56); Harrison (1971 II: 127 n. 3 ) 
tal (D. XLIV 1-2, 42, 44, etc.), de que una acusación o reclamación no es legalmente admisible.

Según acabamos de ver, el sentido originario de $\delta \iota \alpha \mu \alpha \rho \tau u \rho \varepsilon \tilde{v} v$ era el de 'presentar una protesta por medio de un testigo', atribuido al iniciador de la diamatyría; secundariamente, el de 'atestiguar en una protesta', atribuido al testigo de la misma. No obstante, si tuviéramos que reducir a la unidad sus significados y buscar un denominador común para ellos, quizá el más idóneo sería este último, 'atestiguar en una protesta':

a) por medio de un testigo, cuando se trata solo del promotor de la diamatyría, Is. III 3 (§ 3.3.2.2 c.); Is. VI 4-5, 10, 12, 17, 39, 47 (§ 3.3.2.2 d.);

b) directamente, si nos estamos refiriendo al promotor de la diamatyría que es al mismo tiempo el testigo de ésta, D. XLIV 1-2, 42, 44, 46, 54-56 (§ 3.3.2.4.);

c) refiriéndonos al testigo de la diamatyría, Is. II hyp., 2; V 15-18 (§ 3.3.2.2 a, b.);

d) cuando hablamos del promotor de la misma, considerado no como tal, sino como testigo directo de ella, Is. III 3 (§ 3.3.2.3.).

3.3.2.6. Teniendo en cuenta lo anteriormente dicho, traigamos ahora a cola-

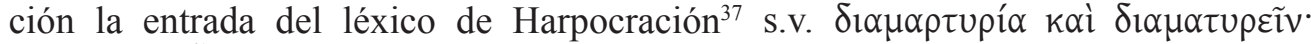

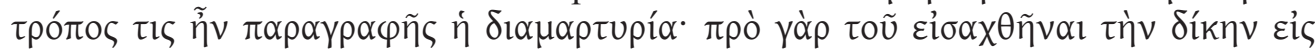

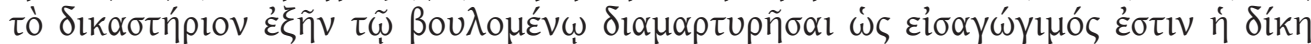

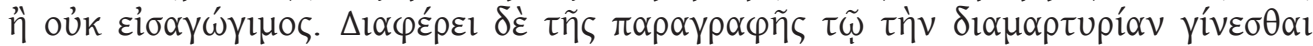

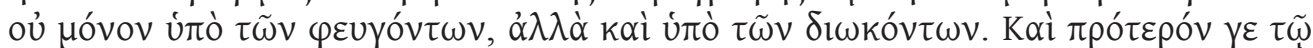

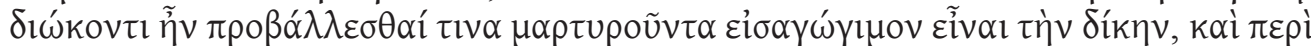

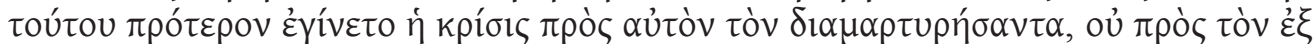

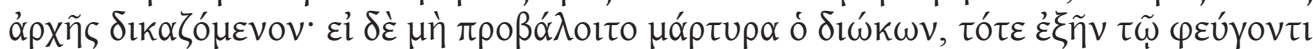

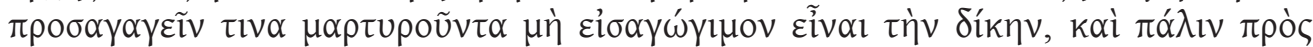

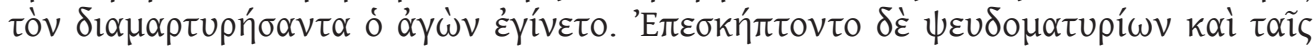

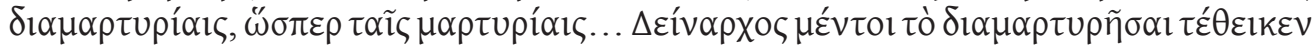

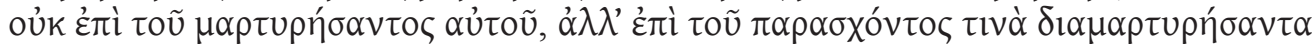

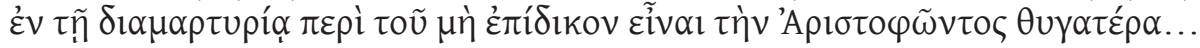

«Protesta testifical y atestiguar en una protesta: La protesta testifical era un tipo de excepción: antes de ser introducida la acción en el tribunal a cualquiera le era posible atestiguar en una protesta que la acción era admisible o no. Se diferencia de la excepción en que la protesta testifical era formulada no solo por los acusados, sino también por los acusadores. Y en primer lugar, al acusador le era posible presentar a uno que atestiguara que la acción era admisible y sobre ello tenía lugar primeramente el juicio frente al mismo que prestó el testimonio en la protesta, no frente al que pleiteaba desde el principio; si el acusador no presentaba un testigo, entonces era posible al acusado hacer comparecer a uno que atestiguara que la acción no era admisible y de nuevo el proceso tenía lugar frente al que prestó el testimonio en la protesta. Impugnaban por falsos testimonios tanto las protestas testificales, como los testimonios... Dinarco, sin embargo, no ha atribuido el hecho de atestiguar en una protesta al testigo propiamente

37 Harrison (1971 II: 124 n. 2). 
dicho, sino al que proporcionó al testigo que prestó en la protesta el testimonio de que no era adjudicable la hija de Aristofonte...».

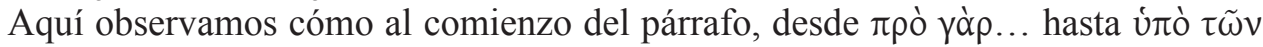

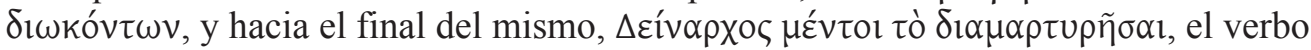
$\delta i \alpha \mu \alpha \rho \tau u \rho \varepsilon \tilde{i} v$ se refiere al promotor de la diamatyría, mientras que en el resto del pasaje alude al testigo del que se sirve el que promovió la diamatyría.

La utilización siempre de $\delta 1 \alpha \mu \alpha \rho \tau \cup \rho \varepsilon \tilde{\imath} v$ para ambos casos se explica porque los atenienses pensaban que tanto el iniciador de la diamartyría como su testigo eran por igual protagonistas de la misma acción. Por lo demás, da la sensación, de que el lexicógrafo en el última parte del texto citado desconoce que el sujeto agente originario de $\delta i \alpha \mu \alpha \rho \tau \cup \rho \varepsilon \tilde{i} v$ era el promotor de la diamartyría, 'presentar una protesta por medio de testigos', y no el testigo de la misma.

3.3.3.1. Si dos o más reclamantes disputaban una herencia, el arconte, después de la instrucción preliminar (anácrisis), trasladaba el proceso de adjudicación de la herencia (diadikasía) al tribunal de justicia y la otorgaba a quien le hubiere correspondido. Cuando la disputa (por ej., Is. VII) se resolvía por este medio, la acción se llamaba directa $(\varepsilon \dot{\theta} \theta u \delta i \kappa i ́ \alpha)^{38}$. En caso de que un reclamante no estuviera de acuerdo con el testimonio prestado por los testigos de su oponente, podía atacarlo

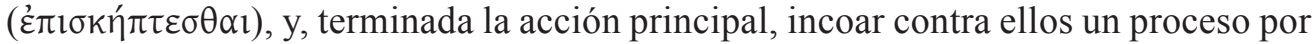
falsos testimonios.

Teóricamente la convicción de alguno de los testigos por falso testimonio, cuando eran varios, bastaba para que el reclamante considerara nula la diadikasía anterior y solicitara de nuevo al arconte una nueva atribución de la herencia. A este respecto Teopompo, heredero de la fortuna de Hagnias, nos refiere lo siguiente (Is. XI 45-46): «Y para mí, la herencia que Hagnias dejó no está todavía segura, pues hay en curso juicios por falso testimonio, y la ley establece que, si se condena a alguien por falso tes-

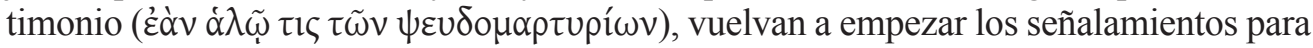

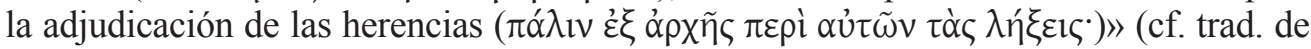
M. D. Jiménez López).

Pero probablemente en la práctica hacía falta un número determinado de testigos (no sabemos cuántos) para que el magistrado juzgara oportuno reabrir el litigio ${ }^{39}$. Como veremos (§ 3.3.3.3.), quizá por eso Diceógenes III, antes de que su rival Menéxeno II, tras conseguir la convicción de un falso testigo, obtuviera la condena de más, le persuadió para que aceptara el reparto de la herencia. En cambio, la condena de todos los testigos por falsos testimonios suponía, sin lugar a dudas, la invalidación de la diadikasía anterior y permitía al reclamante requerir de nuevo sin ningún recelo la adjudicación judicial de la herencia (epidikasía). Esta circunstancia podía conducir, aunque no necesariamente, a una nueva diadikasía, si su oponente u otro nuevo se la disputaba. A este respecto recordemos las palabras atribuidas por un escoliasta a Teofrasto. Según el filósofo, la convicción de falso testimonio solo permitía la reaper-

\footnotetext{
${ }^{38}$ HARRISON (1968 I: 157).

${ }^{39}$ Cf. Harrison (1971 II: 193-194).
} 
tura de un nuevo juicio cuando el caso original había versado sobre herencias, usurpación de derechos civiles por extranjeros u otro caso de falsos testimonios ${ }^{40}$.

3.3.3.2. Mas podía ocurrir que la acción directa, la diadikasía, no tuviera lugar, porque durante la anácrisis un reivindicante interpusiera la objeción o protesta (diamatyría) de que la herencia no era adjudicable, dado que existía un hijo legítimo del difunto. Entonces el arconte no admitía más reclamaciones y atribuía la herencia al heredero en cuestión, a no ser que el testigo que prestó el testimonio o el responsable del mismo fuera perseguido en una acción por falso testimonio. En una palabra, la interposición de una diamatyría impedía la acción directa, es decir, que la diadikasía siguiera su curso y fuera introducida ante el tribunal competente para su resolución. En caso de que el adversario atacara al testigo del reivindicante y emprendiera contra él una acción por falso testimonio, el arconte anulaba la diadikasía inicial ${ }^{41}$, la acción directa, y el litigio se resolvía de distinta manera: la citada acción por falsos testimonios se convertía al mismo tiempo e indirectamente en un juicio por la atribución de

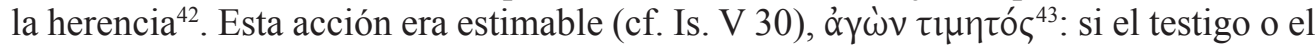
responsable de la diamatyría era condenado, el acusador obtenía como compensación la adjudicación de la herencia ${ }^{44}$; si el testigo era absuelto, el acusador perdía la reclamación ${ }^{45} \mathrm{y}$ el supuesto hijo era considerado heredero ${ }^{46}$. Los ejemplos que veremos en seguida (§ 3.3.3.4.) confirmarán lo que acabamos de decir.

${ }^{40}$ Harrison (1971 II: 194-195 n. 3); MacDowell (1978: 244); Pl. Lg. 397 d, schol. ad loc.

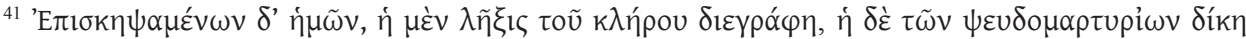

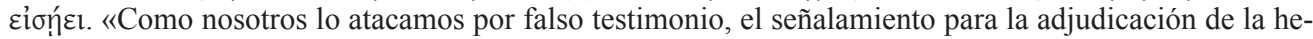
rencia fue tachado y se inició el juicio por falso testimonio», Is. V 17 (cf. trad. de M. D. Jiménez López).

${ }^{42} \mathrm{El}$ amigo de Queréstrato, hijo adoptivo de Filoctemón y nieto de Euctemón, recuerda al tribunal en detrimento de su rival que, para resolver el litigio sobre la herencia de Euctemón, Queréstrato se ha visto obligado a incoar la acción por falsos testimonios contra Androcles, porque éste rehuyó la acción directa, la diadikasía, elevando la protesta (diamartyría) de que existían dos hijos legítimos del difunto: «Pero cuando Queréstrato, acogiéndose a la ley, obtuvo el señalamiento para la adjudicación de la herencia, aunque a cualquier ateniense le era posible disputarla y, entrando ante vosotros en una acción directa, si parecía que exponía argumentos más justos, tomar posesión de ella, Androcles, éste de aquí, interpuso la protesta testifical de que la herencia no estaba sujeta a adjudicación judicial, con lo que privaba a aquél de su disputa y a vosotros de la autoridad de decidir quién ha de ser heredero de los bienes de Filoctemón (propiamente de los bienes de Euctemón, no de Filoctemón)», Is. VI 3 (cf. trad. de M. D. Jiménez López). Contrasta la actitud de Androcles con la de Trasilo II, hijo adoptado en vida por el difunto Apolodoro, que en una diadikasía por su herencia con la hija de Éupolis no eleva una protesta testifical (diamartyría), sino que defiende sus argumentos directamente en ella: «Yo, si hubiera visto que vosotros admitís más las protestas testificales que las acciones directas, habría presentado también testigos de que la herencia no está sujeta a adjudicación judicial en la idea de que Apolodoro me había adoptado como hijo de acuerdo con las leyes. Pero... he venido yo mismo a exponer los hechos...», Is. VII 3 (cf. trad. de M. D. Jiménez López).

La diamartyría solo cerraba la puerta a la resolución directa de la diadikasía en el tribunal de justicia, pero no agotaba la vía judicial: el litigio podía resolverse indirectamente allí a través de una acción de falsos testimonios contra el testigo o responsable de la diamartyría (cf. D. XLIV 57-59).

${ }^{43}$ HARRISON (1971 II: 81).

${ }^{44}$ Is. III 3-6; V 17-19; VI 52-54; D. XLIV 2, 15, 24-26, 61-68, etc.

45 Is. II 44-47; VI 4, 52.

${ }^{46}$ Como ya señaló Paoli, Harrison (1968 I: 157; 1971 II: 129 n. 2). 
3.3.3.3. Abordemos ahora el caso en que, decidida la diadikasía en una acción directa, un reclamante en desacuerdo con el veredicto incoaba una acción por falsos testimonios contra el testigo de su adversario (§ 3.3.3.1). Para ilustrarlo, nos serviremos de Is. V Sobre la herencia de Diceógenes (12-16), algunos de cuyos pormenores ya conocemos.

En una diadikasía a Diceógenes III le fue otorgada toda la herencia como hijo adoptivo de Diceógenes II según un nuevo testamento, que anuló otro anterior. Los parientes próximos del difunto persiguieron entonces por falsos testimonios a los testigos que apoyaron este segundo testamento presentado por Diceógenes III. Menéxeno II, uno de los sobrinos maternos del difunto, logró, en nombre de sus primos, la condena del primero de ellos. Pero Diceógenes III le convenció para que, a cambio de una parte de la herencia, no procesara a los demás testigos. Traicionado luego Menéxeno II por Diceógenes III, que no le entregó lo prometido, se une al resto de sus primos y consigue la condena de los restantes testigos. Invalidada la diadikasía inicial y siendo nulos los testamentos, la herencia de Diceógenes II estaba de nuevo sujeta a adjudicación. Cuando, en virtud del parentesco, los sobrinos maternos del difunto la reclaman, cada uno su parte, se la disputa en una nueva diadikasía Diceógenes III, presentando en la diamartyría a Leócares como testigo de su adopción.

3.3.3.4. Pasemos seguidamente a analizar los casos en que, durante la diadikasía, un reivindicante elevaba una protesta u objeción (§ 3.3.3.2.).

a) Para este propósito todavía nos sigue siendo útil Is. V, Sobre la herencia de Diceógenes. Según acabamos de ver (§ 3.3.3.3), invalidada la primera diadikasía y reabierta la batalla legal por la herencia de Diceógenes II, sus sobrinos la reclaman. Pero Diceógenes III se la disputa en una nueva diadikasía e interpone la protesta por medio de Leócares de que no está sujeta a adjudicación judicial, porque existe un hijo adoptivo, él mismo. Los adversarios atacan entonces al testigo, el arconte anula la diadikasía ${ }^{47}$ y comienza el juicio por falso testimonio, que se convierte al mismo tiempo en el juicio por la atribución de la herencia. El tribunal lo consideró culpable, pero, antes de que dictara sentencia, las partes llegaron a un acuerdo: sus rivales permitieron que Diceógenes III, en lugar de entregar toda la herencia, les cediera las dos terceras partes, de acuerdo con el primer testamento (Is. V 17-19).

Recordemos que la acción por falsos testimonios era estimable (§ 3.3.3.2). Por eso el expositor del discurso, uno de los sobrinos de Diceógenes II, nos dice que podían haber exigido más (Is. V 30): «En efecto, antes, cuando pudimos haber castigado a Diceógenes III y haberle quitado lo que tenía, no quisimos apoderarnos de nada de lo suyo, sino que nos bastaba con recuperar lo nuestro». Además Leócares, al no pronunciarse el veredicto final, se libró de la atimía (Is. V 19) que recaía automáticamente en quien había sido convicto tres veces

${ }^{47}$ Is. V 17; vid. n. 41. 
de falsos testimonios, aparte de la pena que en esta tercera ocasión le hubiera impuesto el tribunal ${ }^{48}$.

b) Como sabemos ya (§ 3.3.2.2.), en Is. III Sobre la herencia de Pirro (1-6), al morir sin descendencia su hijo adoptivo y heredero Endio, tiene lugar una diadikasía por la fortuna de aquél entre File, supuesta hija legítima de Pirro, respaldada por su esposo Jenocles, y la hermana de Pirro, representada por su hijo, el hermano de Endio. Jenocles, por medio de su testigo Nicodemo, interpuso la protesta (diamartyría) de que la herencia de Pirro no estaba sujeta a adjudicación porque existía una hija legítima de éste, File. Resulta obvio por el discurso, aunque no se nos indica expresamente en él, que el hermano de Endio atacó la diamartyría y que, en consecuencia, el arconte canceló la acción directa, la diadikasía. El hermano de Endio, considerando a Jenocles el responsable de la diamartyría, emprendió contra él una acción por falsos testimonios, que, al mismo tiempo, resolvió la atribución de la herencia: la condena del encausado supuso la adjudicación de los bienes de Pirro a la hermana de este último. El hermano de Endio se expresa así (Is. III 5): «Pues si no hubiera parecido que Nicodemo había incurrido entonces en falso testimonio, es evidente que Jenocles habría salido absuelto de su protesta y habría resultado heredera de los bienes de mi tío la que se atestiguó en la protesta que era su hija legítima, pero no nuestra madre» (cf. trad. de M. D. Jiménez López).

c) El siguiente caso (D. XLIV) también lo conocemos ya (§ 3.3.2.5.): Aristodemo demanda la atribución de la herencia de Arquíades como pariente más próximo, pero Leócares, dado en adopción póstuma al difunto por su padre Leóstrato II, eleva la protesta (diamartyría) de que existe un hijo legítimo de Arquiades, él mismo (D. XLIV 46). Aristodemo lo impugna y, cancelada la acción directa (diadikasía), emprende una acción por falso testimonio contra Leócares (D. XLIV 1-2), alegando que la adopción ha sido irregular (D. XLIV 44, 50, 53). Este juicio es al mismo tiempo un proceso por la adjudicación de la herencia, ya que el acusador, el hijo de Aristodemo, reclama como indemnización de su rival la entrega y asignación de la herencia en virtud del parentesco (D. XLIV 2, 15, 24-26, 61-68), fortuna que éste detenta y pretende mantener con su falso testimonio (D. XLIV 11, 16), excluyéndolos (D. XLIV 2, 23-25; cf. 32-34). He aquí sus palabras:

«En efecto, éste es un proceso de atribución judicial de una herencia (diadikasía); por nosotros es disputado el derecho a la sucesión según parentesco, y por estos sujetos según adopción» D. XLIV 7 (trad. de J. M. Colubi Falcó).

«Bien, jueces,... os leerá... la misma ley que atribuye los derechos sucesorios a los linajes y a los más próximos en grado por vía masculina, pues lo esencial del proceso y sobre lo que bajo juramento depositaréis el voto es poco más o menos esto» D. XLIV 14 (trad. de J. M. Colubi Falcó).

«Pero nosotros, jueces, creemos que, cuando hayáis depositado vosotros el voto respecto de esta causa, entonces se debe dar al muerto un hijo adoptivo de

${ }^{48}$ HaRrison (1971 II: 81 n. 6; 127). 
entre nosotros, sus parientes más próximos en grado, con objeto de que la casa no quede desierta» D. XLIV 43 (trad. de J. M. Colubi Falcó).

d) De este otro discurso (Is. II) también estamos ya informados ( $\$ 3.3 .2 .2$ a). En la disputa por la herencia (diadikasía) entre el hijo adoptado en vida por Menecles y el hermano de su padre de adopción, aquél presenta a su suegro Filónides como testigo (diamartyría) de que el legado de Menecles no está sujeto a adjudicación por existir un hijo legítimo, él mismo. El hermano de Menecles ataca al testigo y, clausurada la acción directa, incoa otra por falso testimonio contra éste. El hijo adoptivo le defiende y por sus palabras deducimos que la absolución del testigo supone automáticamente para él la conservación y atribución de la herencia paterna: «Así pues, os pido a todos, ciudadanos, os ruego y suplico que os compadezcáis de mí y que absolváis a este testigo... Sin embargo, mi adversario quiere ahora excluirme de la herencia paterna... Por lo tanto no me privéis, ciudadanos, persuadidos por mis adversarios, de mi nombre, que es ya lo único que me queda de la herencia, y no invalidéis su adopción» Is. II 44-47 (trad. de M. D. Jiménez López).

e) Tenemos igualmente conocimiento $(\S$ 3.3.2.2 d) de que Androcles, pariente próximo de Euctemón, disputó la herencia de este último a su nieto Queréstrato, hijo adoptivo por testamento del difunto Filoctemón, elevando la protesta de que la fortuna de Euctemón no estaba sujeta a adjudicación judicial porque había dejado dos hijos legítimos de un segundo matrimonio, de los que él era tutor. La acción de falsos testimonios que emprendió contra él Queréstrato va a servir también para resolver el contencioso sobre la herencia, bien a favor del acusado, Androcles, si es absuelto (Is. VI 3-5), o a favor de Queréstrato, si aquél es condenado (Is. VI 52-54). He aquí las palabras que pronuncia un amigo de Queréstrato como prueba de lo primero: «En una sola votación y en un único proceso (por falsos testimonios) cree (Androcles) que convertirá a personas que no tienen nada que ver con Filoctemón en hermanos suyos, que él el mismo obtendrá la herencia sin lugar a contestación, que llegará a ser representante legal de su hermana e invalidará su testamento» Is. VI 4 (trad. de M. D. Jiménez López).

Expliquemos ahora lo que hemos dicho en segundo lugar. Aunque Queréstrato mediante esta acción por falsos testimonios se haga con toda la herencia de Euctemón, si Androcles es convicto de falso testimonio, sin embargo este último tendrá oportunidad de revancha: impugnar en una nueva diadikasía la validez del testamento (y de la adopción), presentado por Queréstrato, alegando que Filoctemón nunca testó (cf. Is. VI 5, 52-54, 62). El éxito de la impugnación, desechada la adopción de Queréstrato, le permitiría a Androcles reclamar el matrimonio con una de las dos hijas de Euctemón, la viuda de Quereas, como epiclera, y obtener así la mitad de la citada herencia, ya que la otra mitad correspondería a la otra hija, la esposa de Fanóstrato (cf. Is. VI 46, 57). El ex-

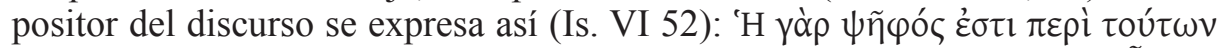

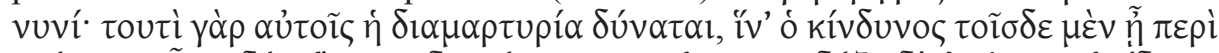

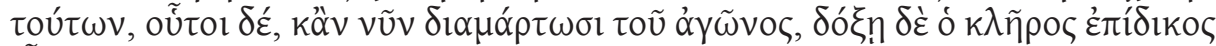

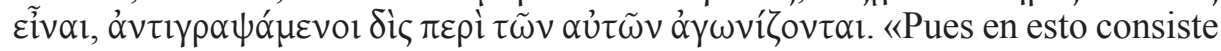


ahora la votación; porque su protesta testifical tiene la siguiente finalidad: que el riesgo en este momento sea para mis amigos (la parte de Queréstrato) y sean nuestros adversarios (la parte de Androcles), aunque pierdan ahora el proceso y parezca que la herencia está sujeta a atribución judicial, los que presenten una contra-acusación y pleiteen dos veces por lo mismo» (cf. trad. de M. D. Jiménez López).

4.1. Por fin, después de este largo, pero necesario recorrido a través del procedimiento judicial ateniense, estamos en condiciones de acometer los problemas que plantea el discurso XXIII de Lisias. El demandante, agraviado repetidas veces por el batanero Pancleón, le citó ( $\pi \rho o ́ \sigma k \lambda \eta \sigma ı)$ ) ante el polemarco, pensando que era meteco. Pero al afirmar éste que era plateense (es decir, a la sazón ciudadano ateniense) del demo de Decelía, el acusador le convocó ante los jueces de la tribu Hipotóntide y se dedicó a investigar más (Lys. XXIII 2). Habiendo averiguado que no era plateense y que había sido condenado en algunos procesos ante el polemarco, incoó también una

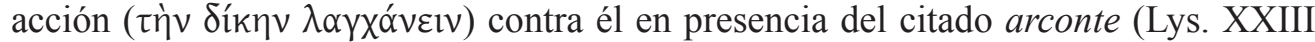
3-4). Esta circunstancia supone que anteriormente el perseguidor rectificó de nuevo y

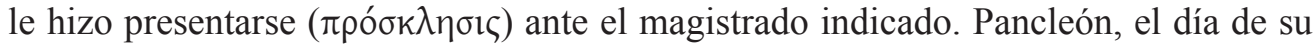

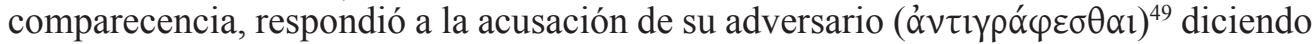
que ésta no era admisible porque era plateense ${ }^{50}$. Como el polemarco no tenía datos suficientes para decidir este asunto, después de este paso previo, permitió al demandante continuar el proceso, convocando a las partes a la instrucción preliminar (anácrisis). Mientras tanto el acusador continuó indagando y descubrió además que Pancleón no era, al parecer, libre, sino esclavo (Lys. XXIII 5-12).

Por lo que podemos deducir ${ }^{51}$, durante esta fase del proceso, en la antomosía (§ 3.3.1.), cuando ambos litigantes ratificaron bajo juramento las declaraciones que habían formulado antes en presencia del magistrado, Pancleón elevó mediante un testigo la protesta, diamartyría, de que el proceso no era admisible porque era plateense. Entonces el demandante atacó y persiguió por falso testimonio al propio Pancleón como responsable de la diamatyría, motivo por el cual el magistrado paralizó la acción principal hasta que se resolviera aquélla ${ }^{52}$. Contra Pancleón (Lys. XXIII) es, pues, el discurso de acusación que pronunció el cliente de Lisias contra su adversario no en

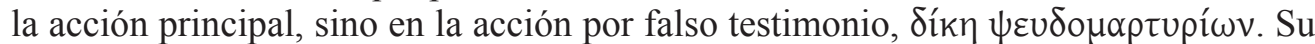
intervención aquí es breve porque le interesa ganar tiempo para poder abordar cuanto antes el proceso original, detenido por el magistrado. Éstas son sus palabras (Lys.

${ }^{49} \S 1.1 .2-1.1 .3 ; 1.3 ; 3.1 .1$.

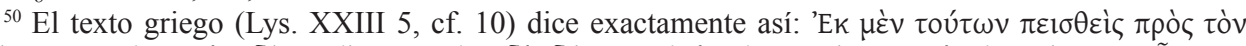

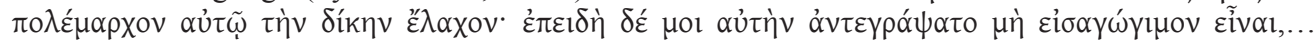

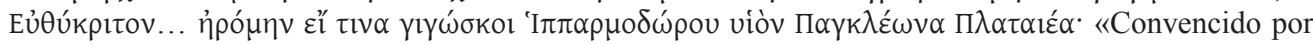
estas razones incoé ante el polemarco un proceso contra él. Pero como me hubiera replicado por escrito que éste no era admisible... pregunté a Eutícrito si conocía a un tal Pancleón, natural de Platea e hijo de Hiparmodoro»» (cf. trad. de L. Gil).

${ }^{51}$ El proceso guarda cierta similitud con el que emprendió Aristódico contra Pancleón, al que alude el demandante en el discurso (Lys. XXIII 13-14; § 3.3.1; 3.3.2.1).

${ }^{52} \S 3.3 .2 .1 ; 3.3 .2 .2 \mathrm{c}, \mathrm{d} ; 3.3 .2 .3$. 


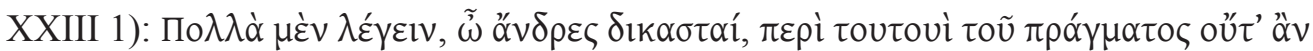

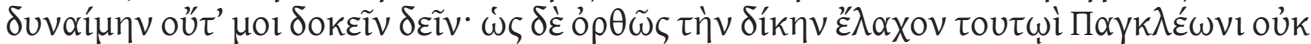

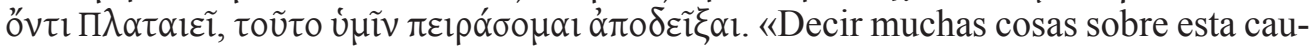
sa, ¡oh jueces!, ni podría ni me parece preciso. Sin embargo, os trataré de demostrar que he incoado este proceso contra Pancleón, aquí presente, por no ser de Platea con los debidos requisitos $\rangle^{53}$ (trad. de L. Gil). Si Pancleón es condenado en la acción por falsos testimonios, la acción principal continúa adelante. Si es absuelto, la acción principal es definitivamente cancelada y el demandante deberá dirigirse a los jueces de su tribu para reabrir el caso. Desconocemos la decisión del jurado en este juicio, aunque, teniendo en cuenta los precedentes (Lys. XXIII 4), es verosímil que el acusador lo ganara.

Como se puede apreciar, la $\alpha \dot{v} \tau \imath \gamma \rho \alpha \varphi n ́$ a la que alude el cliente de Lisias forma parte de los trámites que debe seguir la acción inicial que emprendió contra su adversario (la réplica de éste al cargo presentado); no se trata de un proceso especial. La

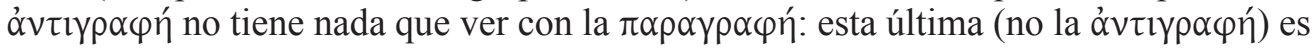
una acción específica, un proceso de excepción que aplazaba el pleito principal hasta que aquél fuera resuelto. De su resultado dependía si la acción original debía proseguir o no $(\S 0)^{54}$.

4.2. Ahora bien, ¿cuál fue la acción inicial que el demandante emprendió contra Pancleón? Como se nos dice que se trata de agravios repetidos en el tiempo (Lys.

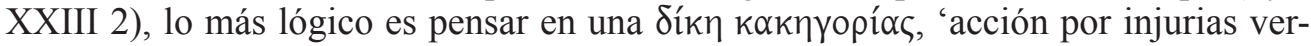
bales', cuya instrucción para los ciudadanos atenienses correspondía a los jueces de tribu.

Sabemos, por ej., que Demóstenes obtuvo la condena de Midias por incompare-

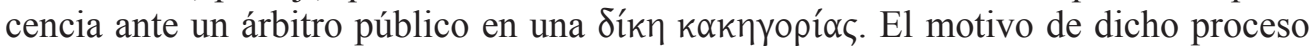
fueron los insultos e improperios que Midias y su hermano Trasíloco, entrando en su casa, espetaron a los que se encontraban en ella: Demóstenes, su hermana, su madre,

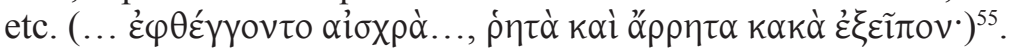

4.3. Para datar el discurso nos pueden servir de referencia los jueces de demo o $\operatorname{tribu}^{56}$. A la caída del régimen de los Treinta Tiranos (403/2 a.C.) o un poco más tarde su número pasó de 30 a 40, por lo que fueron llamados también los Cuarenta. Se asignaban cuatro de ellos a cada una de las diez tribus. En principio se desplazaban por todo el ática, pero cuando, tras la restauración democrática, fueron restablecidos los juicios privados (díkai) el 401/0, ya no viajaban, como se aprecia en este discurso.

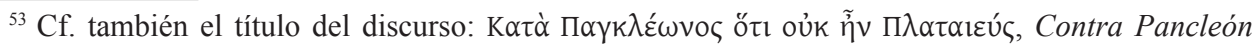
impugnando que fuera de Platea.

${ }^{54}$ La paragrahé tampoco es comparable con la antigraphé en el sentido no técnico de este último término, a saber, el nuevo proceso que el demandado emprendía contra el demandante, como respuesta al iniciado por su adversario. Esta segunda acción de réplica del demandado (antigraphé) no posponía, ni interfería en la primera incoada por el demandante: eran dos pleitos paralelos (§ 1.2; 1.2.1; 1.2.2.; 1.3).

${ }^{55}$ D. XXI 78-79, 81, 83. Vid. también MacDowell (1978: 126-129).

${ }^{56}$ Lys. XXIII 2. Véase al respecto Arist. Ath. LIII 1; Rhodes (1981: 331, 588); HARrison (1971 II: 18-19); MACDowell (1978: 206-207). 
Teniendo en cuenta dicha circunstancia, nos sería posible fecharlo entre el 401/0 y el 386 a.C., año en que fue reconstruida la ciudad de Platea.

\section{BIBLIOGRAFÍA}

Bekker, I. (1814), Anecdota Graeca I, Lexica segueriana, Berlin, Nauck, [reimp. Graz, Akademische Druck- und Verlagsanstalt, 1965].

Bethe, E. (1900-1937), Pollucis Onomasticon, 3 vols., Leipzig, Teubner, [reimp. Stuttgart, 1967].

Calvo Martínez, J. L. (1995), Lisias. Discursos II, Madrid, Gredos.

Colubi Falcó, J. M. (1983), Demóstenes. Discursos privados I-II, Madrid, Gredos.

Coulon, V. - Van Daele, H. $\left(2002^{2}\right)$, Aristophane. Comédies I, Paris, Les Belles Lettres.

DGH (1980-), Diccionario griego-español, Madrid, CSIC.

DindoRF, W. (1853), Harpocrationis Lexicon in decem oratores atticos, 2 vols., Oxford University Press, [reimp. Gröningen, Bouma, 1969].

Fernández-Galiano, M. (1953), Lisias. Discursos I-XII, Barcelona, Alma Mater.

García Domingo, E. (2013), Sicofanta: etimología y significado, Madrid, Ediciones Clásicas.

García Valdés, M. (1984), Aristóteles. Constitución de los atenienses. Pseudo-Aristóteles. Económicos, Madrid, Gredos.

Gernet, L. (1954-1960), Démosthène. Plaidoyers civils I-IV, Paris, Les Belles Lettres.

Gernet, L. - Bizos, M. (1955²), Lysias. Discours II, Paris, Les Belles Lettres.

Gil Fernández, L. (1963), Lisias. Discursos XIII-XXV(vol. II), Barcelona, Alma Mater.

- (2011) Aristófanes. Comedias II, Madrid, Gredos.

Guzmán Hermida, J. M. (1979), Isócrates. Discursos I, Madrid, Gredos.

Hansen, M. H. (19992), The Athenian Democracy in Age of Demosthenes, London, Duckworth/Bristol Classical Press.

HARRISON, A. R. W. (1968-1971), The Law of Athens I-II, Oxford, University Press.

Isaeger, S. \& Hansen, M. H. (1975), Aspects of Athenian Society in the Fourth Century B.C., Odense, University Press.

Jiménez López, M. D. (1996), Iseo. Discursos, Madrid, Gredos.

Lipsius, J. H. (1905-1915), Das attische Recht und Rechtsverfahren, Leipzig, O. R. Reisland, [reimp. Hildesheim, G. Olms, 1966].

López Eire, A. (1985), Demóstenes. Discursos políticos II, Madrid, Gredos.

Lucas de Dios, J. M. (2002), Esquines. Discursos, Madrid, Gredos.

MacDowell, D. M. (1962), Andokides, on the Mysteries, Oxford, University Press.

- (1978), The Law in Classical Athens, London, Thames \& Hudson.

- (1990), Demosthenes Againts Midias, Oxford, University Press.

Martin, V. - BudÉ, G. (1927), Eschine. Discours I, Paris, Les Belles Lettres, [reimp. 1962].

Mathieu, G. - Brémond, É. (1929), Isocrate. Discours I, Paris, Les Belles Lettres, [reimp. 1963].

Mathieu, G. - Haussoullier, B. (1922), Aristote. Constitution d'Athenes, Paris, Les Belles Lettres, [reimp. 1972].

Ramos Jurado, E. A. (2002), Platón. Apología de Sócrates. Fedón, Madrid, Alma Mater.

Redondo Sánchez, J. (1991), Antifonte. Andócides. Discursos y fragmentos, Madrid, Gredos. 
Rhodes, P. J. (1981), A Commentary on the Aristotelian Athenaion Politeia, Oxford, University Press.

Roussel, P. (1960²), Isée. Discours, Les Belles Lettres.

Rubinstein, L. (1993), Adpotion in IV Century Athens, Museum Tusculanum Press. University of Copenhagen.

Todd, S. C. (1993), The Shape of the Atenian Law, Oxford, Clarendon Press.

- (2000) Lysias, Austin, University of Texas Press.

Willian Chase Greene - Charles Pomeroy Parker - John Burnet - Frederic de Forest Allen (1988), Scholia Platonica, Hilesheim, Olms. 